\title{
Ownership change, institutional development and performance
}

\author{
Anzhela Knyazeva ${ }^{\text {a }}$, Diana Knyazeva ${ }^{\text {a,* }}$, Joseph E. Stiglitz ${ }^{\text {b }}$

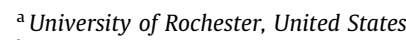 \\ ${ }^{\mathrm{b}}$ Columbia University, United States
}

\section{A R T I C L E I N F O}

\section{Article history:}

Received 31 July 2011

Accepted 9 February 2013

Available online $\mathrm{xxxx}$

\section{JEL classification:}

G38

G39

L33

G32

K00

Keywords:

Ownership change

Property rights

Privatization

Performance

\begin{abstract}
A B S T R A C T
This paper conducts a cross-country empirical study of the impact of institutions and agency conflicts on ownership reforms and their implications for changes in performance and efficiency. We examine two main questions. First, we evaluate the effects of certain property rights and institutional quality measures on performance and efficiency. We find that property rights and contracting rights protections contribute to stronger post-privatization performance. Second, we ask whether sectors undergoing changes from state to private ownership exhibit better or worse performance than sectors remaining public. We find an insignificant effect of privatization in ordinary least squares estimates and a negative short-term effect after correcting for endogeneity of privatization decisions that disappears in the long run, consistent with recently privatized enterprises facing short-run costs of restructuring and the challenges of mitigating agency and expropriation concerns.
\end{abstract}

(c) 2013 Elsevier B.V. All rights reserved.

\section{Introduction}

In the eighties and early nineties policy makers and academics endorsed privatization reforms that have since been conducted in many developed and emerging market countries. More recently attention has shifted to the varying outcomes of privatization programs, some of which were implemented with little to moderate success and enveloped in accusations of nepotism and expropriation of property rights. Separately, law and finance research has highlighted the role of institutions for capital market development and firm performance (for example, La Porta et al. (1998) and subsequent work). In an earlier paper, we have examined the effects of access to capital on the performance of privatized enterprises (see Knyazeva et al., 2009). In this paper we focus on the performance and efficiency implications of property rights in the context of the outcomes of privatization reforms. Our methodology addresses crucial selection concerns inherent in the analysis privatization decisions. In addition, we conduct a telecom industry study to evaluate alternative dimensions of operating efficiency and analyze the effects of

\footnotetext{
* Corresponding author. Address: William E. Simon Graduate School of Business Administration, University of Rochester, New York, NY 14627, United States. Tel.: +1 5852753211.

E-mail address: diana.knyazeva@simon.rochester.edu (D. Knyazeva).
}

property rights on the attributes of the actual privatization. We conclude with a discussion of policy implications for the design of privatization reforms.

First, we examine the determinants of post-privatization performance focusing on the role of institutions and accounting for selfselection into the privatization group. We hypothesize that property rights protections are instrumental to post-privatization performance as they both protect recently privatized firms against government expropriation and enhance new owners' incentives to restructure the firm and create strong intra-firm monitoring mechanisms. We find significant positive property rights effects on operating performance. A one standard deviation increase in the index of property rights protection against expropriation is associated with up to $1.3 \%$ higher average profitability. Although selection bias is statistically significant, the property rights effect remains qualitatively similar after we account for self-selection into the privatization reform group.

In addition to the protection of private property rights against expropriation by the government, the strength of contracting rights and the effectiveness of the legal system that affects interaction with private counterparties post-privatization are also important for post-privatization profitability. For instance, a onestandard deviation (0.71) decrease in legal formalism (that boosts contracting rights by easing contract enforcement) has a 1.45 percentage point positive effect on profitability. 
While political stability and government effectiveness have a generally favorable effect, most political institutions measures do not significantly affect post-privatization performance. Profitability after privatization is most directly tied to the protection of private investors against expropriation and better enforcement of contractual rights.

Second, we test whether recently privatized sectors outperform public sectors, controlling for institutions and other characteristics as well as the endogeneity of privatization. On the one hand, privatizations can improve performance and bring about efficiency gains generated due to removal of ill-incentivized government administration and introduction of private owners motivated by value creation. On the other hand, the privatization process imposes costs and tradeoffs that may limit profitability in the short run (direct restructuring costs, the challenges of managing intrafirm incentive conflicts and the risk of expropriation of the newly private enterprise by the government, as well as adjusting to the removal or reduction of government subsidies offered to formerly state-owned enterprises). Moreover, with inadequate corporate governance laws, management may "tunnel" the resources of the firm for their own purposes. Empirically, we find that governments are more likely to privatize firms that perform well, biasing traditional tests of performance effects of privatization. Although the privatization group performs well on average, after correcting for endogeneity, we find that privatizations exhibit weaker performance relative to public sectors in the short run. The findings highlight the importance of recognizing endogeneity and the nontrivial performance challenges facing newly private enterprises in a framework with agency and expropriation costs. The tradeoff is most pronounced for enterprises that enjoyed subsidies prior to privatization. They experience negative effects for up to 10 years. In the long run, the effect becomes insignificant.

Third, we examine characteristics of privatization transactions. We find significant evidence of matching of acquirers and privatization targets based on the institutional environment quality. This suggests that, as with cross-border acquisitions in general, institutional compatibility of buyers and targets is an important consideration in privatization deals; that is, countries with strong property rights (as reflected in our measure) look for and seem attractive to firms in countries with strong property rights. In addition, strong property rights in the privatization target country are associated with a lower likelihood of diversifying deals (that is, deals in which the acquiring firm buys a firm in a different industry), deals with foreign buyers, or employee buyouts.

The rest of the paper is organized as follows. Section 2 develops hypotheses and testable predictions, discusses existing literature, and summarizes the contribution of our study. Section 3 discusses data, variables, and methodological issues due to endogeneity and selection bias. Section 4 presents the main empirical results and robustness analyses. Section 5 concludes.

\section{Hypotheses}

\subsection{Hypotheses and empirical predictions}

\subsubsection{Property rights in the privatization country and post- privatization performance}

The main question of interest is the role played by the property rights environment and institutional quality in post-privatization performance (within the privatization sample). We hypothesize that the quality of the institutional environment is a significant determinant of performance following privatization and we expect better performance of privatized sectors in the presence of good institutions. Like other privately owned companies, recently privatized enterprises are now exposed to government rent-seeking, through direct expropriation of cash flows or assets, the corruption 'tax' and related property rights risks (for instance, recently privatized enterprises are especially vulnerable to a complete asset seizure, should the privatization be opportunistically reversed). Later, we will explain why our measure of "property rights" actually is a proxy for certain aspects of institutional quality-that get reflected not just in the performance of private companies subject to expropriation risk, but also in that of public enterprises. Besides permitting private owners to invest efficiently by limiting government expropriation, strong property rights protections also encourage them to adopt a long-term view and establish robust monitoring mechanisms aimed at resolving intra-firm agency conflicts. Therefore, the new owners' incentive to design adequate monitoring mechanisms, as well as fire entrenched insiders and hire and retain better management, is stronger if overall institutional quality is good. ${ }^{1}$

Stronger "institutional quality" not only protects against government expropriation, but also against private abuses associated with inadequate corporate governance (e.g., tunneling). Similarly, private sector efficiency requires the enforcement of contracts. While there are many details of the institutional and legal regime that matter, we have data only on overall assessments of certain attributes of the legal system. We set aside these crucial distinctions, to hypothesize that property rights (or broader measures of institutional quality) have a positive effect on post-privatization performance among privatized enterprises.

Further, we ask whether there are spillover effects of property rights in the buyer country on the performance of the privatized enterprise. This unanswered question is important for two reasons: (i) international buyers are often involved in privatization transactions; and (ii) the buyer is likely to become heavily involved in any restructuring that will occur within the privatized enterprise after privatization. Additionally, strong property rights in the buyer country may cause spillovers and become consequential for postprivatization performance of the privatized enterprise. As a caveat, institutional quality as reflected in our metrics in the country of the acquirer may affect the organizational performance of the acquiring company - and thus the performance of the privatized company; or it may be correlated with other attributes (e.g., the quality of the education system). Our analysis does not enable us to distinguish among these alternative hypotheses.

\subsubsection{Performance in the privatization versus government-owned groups}

We compare performance within the sample of industries in which there has been a privatization to that of the sample remaining public. A common argument is that privatizations remove obstacles to proper resource allocation posed by government control and facilitate the dismissal of poorly motivated governmentappointed managers whose objective function is vastly different from value maximization. Thus, privatization reforms can jumpstart performance improvements in formerly state-owned enterprises (SOEs). By comparison, sectors that remain public continue to lag behind, exhibiting incrementally worse performance due to ongoing investment inefficiencies and agency costs, resulting in the empirical prediction that privatized sectors outperform sectors remaining in government ownership. (In our earlier paper, we provided another reason for improved performance: in cases of governments facing severe budget constraints, there can be an underinvestment in publicly owned enterprises, which is corrected under private ownership.)

\footnotetext{
Good institutional quality also contributes to greater effectiveness of the privatization process, whereby buyers with the highest valuations become the new owners, helping maximize efficient allocation of resources in newly private firms.
} 
Alternatively, privatized industries could actually do worse than publicly owned industries in the several years following the ownership reform. Importantly, the full benefits of private ownership do not arise automatically or immediately after privatization. Instead, firms enter a transition period, during which they may post losses or perform poorly.

Private owners have to deal with the direct costs of restructuring (including any last-minute asset stripping that may have preceded the privatization deal). In addition, while agency problems arising from government ownership may be mitigated, private owners need to address intra-firm agency conflicts due to separation of (usually, more disperse) ownership and control as well as manage the new risk of expropriation of the now private firm by the government. If the state-owned enterprise used to rely heavily on subsidies, such subsidies are most likely going to be reduced or eliminated altogether after privatization as soft budget constraints are lifted, which may mean a short-term reduction in profitability that lasts until long-term efficiency improvements are realized. In that case, performance need not improve in the short run. Thus, the alternative hypothesis is that privatized enterprises do not outperform those remaining public and that property rights protections and contracting institutions are more significant in determining performance than the ownership regime itself.

As an aside, although our focus is on privatized enterprises, we expect that property rights variables might be significant for public sector performance as well, as a measure of overall quality of public governance and effectiveness of government administration. (Note, to the extent that is true, it implies that our measure reflects far more than property rights, since there is no risk of government expropriation of government enterprises.)

\subsubsection{Privatization deal characteristics}

Finally, we will examine the relevance of property rights in the privatization country for the deal characteristics and the matching of buyers and privatizing governments. Specifically, we expect that privatizations will involve matching of buyers and targets from compatible legal environments. Short of fully liquidating the privatized enterprise, the buyer is likely to retain substantial asset exposure to the privatized enterprise's legal environment. Prospective buyers (corporations or investors) coming from a low expropriation risk environment are less likely to be able to handle government rent-seeking and effectively mitigate expropriation risks to the assets of the privatization target. Thus, buyers from compatible legal environments are more likely to become engaged in the privatization transaction.

\subsubsection{Related work and this paper's contribution}

This paper relates to earlier literature on privatization. Some studies looked at individual firms' or countries' ownership reforms and outcomes (see, e.g., La Porta and Lopez-de-Silanes, 1997; Anderson et al., 1997; Noam, 1998; Sun and Tong, 2003²). Birdsall and Nellis (2003) assess distributional effects of privatization. Most multi-country studies evaluate performance changes in the privatization sample and find that performance improves after privatization (see, e.g., Boubakri and Cosset, 1998; Megginson et al., 1994; D'Souza and Megginson, 1999; Bortolotti et al., 2001; Dinc and Gupta, 2011; Gupta, 2005; Mathur and Banchuenvijit, 2007; for a review, see Villalonga, 2000). Wallsten (2001) finds positive effects of establishing a regulator prior to privatization on reform outcomes. Other studies similarly find a positive link between private ownership and performance (see, e.g., Dewenter and Malatesta, 2001; Boardman and Vining, 1989; Ehrlich et al., 1994; for a review, see,

2 Omran (2004) examines newly private Egyptian firms and finds that they do not outperform state-owned enterprises. e.g., Megginson and Netter, 2001). However, this literature, for the most part, does not address the problem of endogeneity. Notable exceptions are Gupta et al. (2008), Sabirianova et al. (2012), Claessens and Djankov (1998) and Dinc and Gupta (2011), which confirm positive performance effects of privatization in samples covering Czech Republic, Czech Republic and Russia, seven Central and Eastern European countries, and India, respectively.

This paper also relates to the broader law and finance literature (e.g., La Porta et al., 1997, 1998, 1999, 2000; Djankov et al., 2008; and subsequent work). However, our focus is much more specific to the performance of privatizations. There is a large theoretical literature that argues for the importance of creating good institutions (including corporate governance laws) prior to privatization and shows that the failure to do so accounts for the poor record of countries that engaged in rapid privatizations through shock therapy (e.g., Stiglitz 2000a, b, 2002; Hoff and Stiglitz, 2008; Ellerman and Stiglitz, 2000; and the studies cited there). D'Souza et al. (2005) and Boubakri et al. (2005) find that corporate governance and government ownership play an important role in firm performance. Godoy and Stiglitz (2007) focus on the relation between privatization speed and institutional development. They find that the speed of privatization is negatively associated with growth, but legal institutions have a positive and highly significant effect on growth. However, the paper does not test the effects of varying institutional, regulatory and other characteristics for the outcomes of privatization and focuses instead on privatization speed and design.

We are less directly related to the literature on acquisitions (e.g., Erel et al., 2012; Masulis et al., 2007; Kang and Kim, 2008; Kedia et al., 2008; Moeller et al., 2004). Our research focus is much more specialized as we look at one subtype of acquisition deals, which entails government-owned targets.

We contribute to the existing literature by considering overall privatization performance and key determinants of success of ownership reforms.

First, we provide new evidence on the differences in performance between sectors where privatization has and has not occurred that explicitly accounts for the endogeneity of the privatization decision. Countries and industries undergoing privatizations are far from being randomly selected. Unobservable characteristics that are potentially behind future performance could also be related to the privatization decision. Hence, ordinary least squares estimates of privatization effects yield spurious evidence. Indeed, we find that after accounting for the endogeneity of privatization decisions, the privatization group underperforms the group of sectors remaining public, all else equal. This finding is opposite to most related evidence and it underscores important challenges in post-privatization performance and raises questions about the optimality of privatization decisions.

Second, we document the essential role of institutional, legal, and regulatory environment factors for the outcome of privatization. We account for selection bias and find consistent results. Moreover, we isolate spillover effects of the property rights environment in the buyer country on the performance of the sector undergoing privatization.

Lastly, we find that property rights in the privatization country have significant predictive power for buyer selection and design of privatization transactions.

\section{Data}

\subsection{Sample}

Our main sample is based on Privatization Barometer (PB) privatizations in 'Old' (Western) and 'New' (Central and Eastern) European economies. Our first set of tests focuses on property rights 
and institutional quality effects on post-privatization performance, so instances where no deals were reported in a given year are excluded. Our second set of tests uses the entire sample of Compustat Global (CG) industries for European countries, including those for which no privatization transactions were reported. (We recognize that some ownership changes may not have been recorded or may have predated the PB data series.) The availability of country level data on property rights and macroeconomic controls affects sample size. For robustness, where indicated we use the alternative sample that extends beyond Europe, based on acquisitions of government-owned companies by non-government buyers reported in Securities Data Company (SDC) Platinum. Since, unlike PB, it also provides information on the nation and identity of acquirer (where disclosed), we also use this sample to analyze the effects of acquirer country property rights on privatization outcomes. PB lacks firm level IDs for privatized enterprises while SDC provides IDs for only some privatized enterprises and has missing characteristics data for most privatization targets. Since we rely on a set of controls to conduct a more meaningful multivariate examination of performance, we aggregate data to the two-digit SIC industry level for each country and year. We use 1-year leads of profitability, resulting in the 1988-2009 period for the main sample, due to CG data availability (the sample period begins in 1990 with alternative property rights measures).

Second, we analyze deal level data on privatization design and buyer selection using SDC data. For this analysis we use property rights and industry and macro controls, so the sample period is 1985-2010 (begins in 1990 with other expropriation risk measures). Privatizations are identified, as with the sector sample, using government ownership status of the target and non-government ownership of the buyer. Acquirer and target nations must be disclosed and property rights data must be available for both. To construct the remaining variables of interest, we use information on buyer and privatization target primary industry, buyer status as a privately held or publicly listed firm, and percentage stake the buyer is seeking to acquire (or own) through the privatization transaction.

As an additional test, we conduct a sector study of telecom privatizations (e.g., also see Knyazeva et al., 2009). The telecom sector experienced privatization reforms in a number of developing and developed economies in the eighties and nineties. Telecoms face nontrivial expropriation risks due to substantial tangible assets tied to the country of location and the need for regulatory approvals. Further, many telecom privatizations were driven by a need to raise revenue for fiscally constrained governments, especially in developing economies. While profitability data may be vulnerable to accounting differences or misreporting, the telecom study uses operating efficiency data from the International Telecommunications Union (ITU), which is more comparable across economies. Telecom privatization years are obtained from Wallsten (2002). However, we also recognize the limitations of small telecom sample size, which weakens the power of the test, and interpret the telecom results as suggestive rather than conclusive, with more definitive tests of our hypotheses performed on the main sample.

\subsection{Variables}

\subsubsection{Analysis of performance outcomes across sectors}

Following much empirical corporate finance work, we measure operating performance by the ratio of operating income before depreciation to assets, in percentage terms. We use 1-year leads to mitigate causality concerns (more on causality approach in Section 3.3).

It is essential to control for other characteristics potentially associated with performance as well as institutional environment or ownership changes, so we account for differences in size, growth opportunities, income per capita, and competition in the industry (using a sales-based Herfindahl index). We also control for differences in the scope of privatization reforms (number of deals, relative value, and average stake), since more extensive privatization programs can generate more significant performance improvements or expropriation risks. Tests using the SDC sample also incorporate information about property rights in the acquirer country to examine their ramifications for post-privatization performance.

\subsubsection{Property rights and institutional environment quality}

It is important to distinguish property rights protection from overall institutional environment quality.

The first two measures focus on property rights protection from expropriation. Our first measure is the Investment Country Risk Guide (ICRG) country rating of property rights. Higher values of the rating, which varies from 0 to 100 , reflect stronger protection of property rights against government expropriation. It is a popular measure of political risk in the law and finance literature. It is supplemented by data from the World Governance Indicators (WGI) dataset provided by the World Bank and Kaufmann et al. (2009) (KKM). We average scores, each of which varies between -2.5 and 2.5, for six dimensions of property rights quality (rule of law, control over corruption, political stability, voice and accountability, government effectiveness, and regulatory quality) as well as focus on individual aspects of the index, namely, control of corruption, rule of law, and political stability, which are most directly related to potential for property rights erosion due to government corruption, political coups, or failure of the courts and law enforcement authorities to protect property owners.

Some tests also consider French legal origin as a measure of preexisting weak institutional quality, following La Porta et al. (1997, 1998). In addition, potential for political conflict can cause a backlash against large scale privatizations, of which telecoms are a salient example, increase the risk of their reversal, and depress worker productivity at privatized firms. We use ethno-linguistic fractionalization to measure potential for conflict, following La Porta et al. (1999). ${ }^{3}$

\subsubsection{Privatization deal attributes}

We consider several important privatization transaction characteristics in the deal level analysis. First, we consider property rights in the buyer's country, in the full sample of privatizations and in the cross-border privatization subsample. Second, we consider indicator variables for buyer type, including buyers that are privately held (versus publicly listed) and cases where employees are represented on the buy side. Third, we examine diversifying privatization deals, since deals involving buyers and targets from different industries in general have been linked to value destruction, resulting in a "diversification discount" for firms that operate in different industries instead of focusing their core operations in one sector (for more, see, e.g., Amihud and Lev, 1981). Further, we include an indicator for cross-border deals since greater distance between acquirers and targets has been linked to worse performance (Kang and Kim, 2008; Kedia et al., 2008). Finally, we examine the stake being privatized in the specific transaction as well as the total percentage stake that the acquirer is seeking to own in the privatization target after the deal is completed.

Variable definitions and descriptive statistics for the main variables are summarized in Appendix A.

\footnotetext{
It can be viewed as a supplement to the political stability measure.
} 


\subsubsection{Telecom study}

We use telecom sector output (main lines) per employee to capture operating efficiency. The use of a real measure of operating efficiency offers several advantages. Unlike profitability, it is not affected by regulatory interventions in price setting mechanisms or differences in reporting standards before and after privatization and in privatized versus public subsamples. It also incorporates the net effect of intra-firm labor conflicts, which may arise in the privatization setting. To account for the fact that all (privatized and public) sectors likely saw growth in telephone lines efficiency between the start and the end of the sample period, we compare changes in average operating efficiency in the privatization and state-owned samples between 1987-1989 and 2000-2002 (we cannot use privatization year based windows since we require a comparison public subsample). ${ }^{4}$

The analysis incorporates several sector-specific controls: an indicator for independent telecom regulator presence; an indicator for local, long-distance, and international telephony competition; full telecom privatization dummy; and late privatization indicator, to capture technology and learning effects. Data is based on Li and Xu (2002) and Wallsten (2002). We use several macro controls, including population size, initial or current income per capita, fiscal balance, credit, inflation, and foreign direct investment flows. To control for pre-existing quality of life effects on worker productivity, we use life expectancy at birth. Data is obtained from the World Bank's World Development Indicators (WDI). Since the telecom sector sample contains African countries, which might follow a different growth trajectory and have vastly different initial sector conditions, we include the sub-Saharan Africa dummy control in this sample. We do not use region or group aggregates, so imputation of missing macroeconomic observations is not a concern. However, due to the lower frequency of certain property rights and political risk indicators, imputed values are used for missing years. Omitting filled-in years results in qualitatively similar inference, albeit within a smaller sample.

\subsection{Endogeneity and selection}

The analysis of privatization effects on performance can be confounded by endogeneity, which is overlooked in most existing studies of privatization. ${ }^{5}$ The common observation in existing literature that privatizations improve performance may be due to nonrandom choice of state-owned enterprises to be privatized. For instance, if governments are seeking to raise revenue fast, as has been the case for a number of large privatization programs run by fiscally constrained governments (e.g. telecom privatizations in Latin America), the most lucrative assets, including the best performing SOEs, may be sold off first. Alternatively, a government seeking to maximize efficiency may hold off on privatizing well performing SOEs because they are already run efficiently and a switch to more disperse private ownership is unlikely to generate improvements. In either instance, if past performance relates to future performance, the relationship with privatization will be spurious. A related concern involves selection bias in the analysis within the privatized subsample: selection into the subsample is a function of unobserved characteristics related to performance. In both cases estimation with ordinary least squares will bias estimates. We therefore use a selection model for the analysis of the privatization sample and a treat-

\footnotetext{
4 The growth in cell phone use is not a big concern for most countries during our sample period (1990-2000). In any case, it should not bias our tests as long as substitution between cell and land line service is not systematically dependent on privatization.

${ }^{5}$ A recent exception is Dinc and Gupta (2011), which finds positive performance effects of privatization in a sample of Indian privatizations, whereas we find negative effects after controlling for endogeneity in a broad cross-country sample.
}

ment effects model for the analysis of privatization effects in the full sample. 6

Estimates of the determinants of the privatization decision are shown in Appendix B for the main sample and Appendix D for the telecom sample (in the latter, the smaller sample size lowers the significance of some estimates). Large enterprises are more likely to be prioritized for privatization purposes, consistent with the possibility of raising more revenue. Larger countries, as measured by population size, seem to be more likely to privatize. Countries with bigger governments, as measured by the level of government expenditure in GDP, have more state-owned entities to divest. Although governments may be more reluctant to privatize labor-intensive industries to avoid large-scale layoffs by new private owners, the effect is not significant. Initial legal origin and income effects are sensitive to the sample used. In the main sample, countries with common law legal origin are on the margin more likely to privatize, but the effect is not significant in the telecom sample. Within the main European sample, poorer countries are more likely to privatize as they are the ones catching up on ownership reforms during our sample period (nineties and 2000s). In the global telecom sample from the late eighties and nineties, richer countries led emerging markets in the wave of privatizations.

\section{Results}

4.1. The effects of property rights, contracting environment, and political institutions on the performance of privatized industries

We begin by examining post-privatization performance as a function of various dimensions of protection of private property rights, contracting and legal environment, and political institutions in the privatizing country. Attribution of the effect of property rights protection on privatization outcomes to specific characteristics of the legal and institutional environment is crucial for our understanding of the role that institutions play in the success of ownership reforms. We seek to evaluate whether the most significant effects are due to (i) protection of private property owners from government expropriation or corruption; (ii) strength of the judicial system and enforcement of contractual rights between private sector counterparties since firms will transact mainly with private sector counterparties post-privatization; or (iii) overall quality of political institutions and accountability of top political officials (less likely, but could be correlated with the property and contracting rights variables). Answering these questions would not only help predict privatization successes more clearly but also potentially provide policy makers with inference on optimal design of legal, contracting and political institutions requisite for the success of newly private enterprises.

At first glance, property rights protection from expropriation, political accountability, and quality of the legal regime and enforcement of contractual claims are intertwined. However, recent work by Acemoglu and Johnson (2005) and Fernandes and Kraay (2007), among others, has attempted to differentiate the institutions that relate to contracting and contract enforcement between counterparties from those that protect property rights of private owners from government expropriation or rent seeking by officials. Moreover, in some instances, even when political institutions and expropriation protections are underdeveloped, an effective judiciary system can still serve as an enforcer of private

\footnotetext{
${ }^{6}$ We also use instrumental variables estimation as an alternative. Both yield similar inferences. Treatment effects estimation yields more efficient estimates when the endogenous variable is binary, as is the case for privatization, so we use it for most of the analysis.
} 
Table 1

The effects of property rights on the performance of privatized sectors.

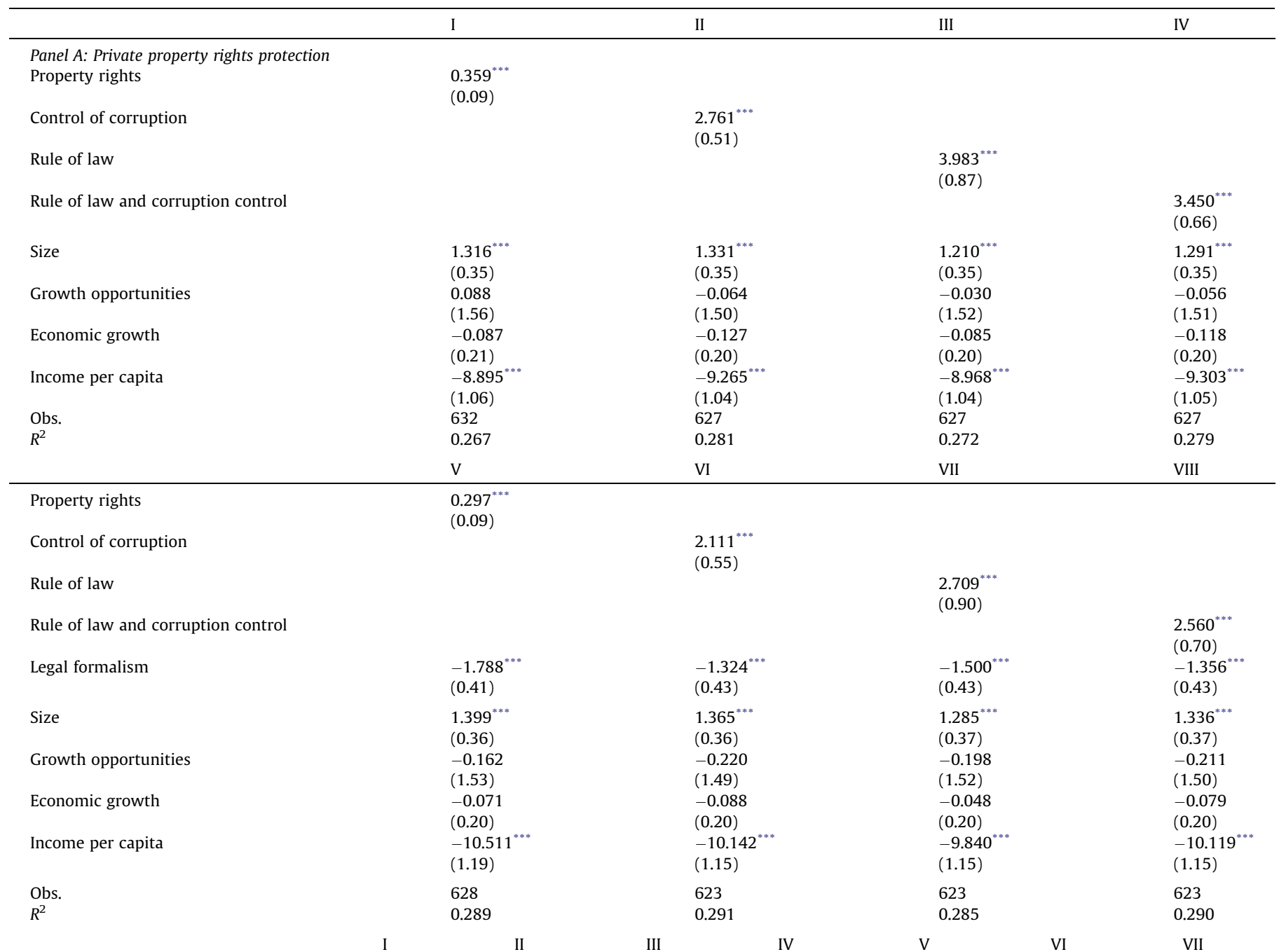

Panel B: Contracting institutions and legal system

Legal formalism

Difficulty of enforcing contracts (procedures)

Difficulty of enforcing contracts

(days)

Effectiveness of the judicial system

Courts

Legal system

Legal system and contract enforcement

Size

Growth opportunities

Economic growth

Income per capita

Obs.

$\mathrm{R}^{2}$

Panel C. Political system and government effectiveness

Constraint on the executive

\section{$-2.043^{* * *}$}

(0.40)

$-0.147^{*}$
$(0.06)$

Voice and accountability

0.565

(0.64)

$1.277^{* * * *}$
$(0.37)$
-0.216
$(1.55)$
0.047
$(0.20)$
$-8.659^{* * *}$
$(1.10)$
628
0.278

$1.170^{* * *}$
$(0.36)$
0.003
$(1.62)$
0.032
$(0.20)$
$-7.222^{* * *}$
$(1.0)$
632
0.257
$-0.004^{* * * *}$ $(0.0)$

$2.306^{* * *}$

$(0.27)$

$0.824^{* * * *}$

$(0.20)$

$\begin{array}{llll} & (0.20) & & \\ & & 0.859^{* * *} & \\ & & (0.23) & 0.928^{* * *} \\ & & & (0.22) \\ & & & 1.527^{* * *} \\ 1.191^{* * * *} & 1.527^{* * *} & 1.530^{* * *} & (0.39) \\ (0.35) & (0.39) & (0.40) & -0.192 \\ 0.146 & -0.197 & -0.204 & (1.72) \\ (1.51) & (1.69) & (1.72) & -0.207 \\ -0.090 & -0.206 & -0.159 & (0.25) \\ (0.19) & (0.25) & (0.25) & -8.729^{* * *} \\ -18.079^{* * *} & -8.870^{* * *} & -8.786^{* * *} & (0.99) \\ (1.83) & (1.05) & (1.03) & 550 \\ 612 & 550 & 550 & 0.286 \\ 0.315 & 0.286 & 0.282 & \end{array}$

$(0.22)$

(0.39)

$-0.192$

(1.72)

$8.729^{* *}$

0.286 
Limited government

Government effectiveness

Regulatory quality

Regulations

Political stability

Size

Growth opportunities

Economic growth

Income per capita

Obs.

$R^{2}$
$-0.276$

(0.27)

$3.457^{* * *}$

$(0.72)$

$$
-0.428
$$

(1.19)

\begin{tabular}{lll} 
& $(0.34)$ & \\
& & $2.511^{* *}$ \\
& & $(0.98)$ \\
$1.095^{* * *}$ & $1.228^{* * *}$ & $1.231^{* * *}$ \\
$(0.35)$ & $(0.36)$ & $(0.36)$ \\
0.072 & -0.083 & 0.138 \\
$(1.58)$ & $(1.55)$ & $(1.56)$ \\
0.051 & 0.050 & -0.067 \\
$(0.22)$ & $(0.20)$ & $(0.21)$ \\
$-6.177^{* * *}$ & $-6.918^{* * *}$ & $-7.203^{* * *}$ \\
$(1.01)$ & $(0.95)$ & $(0.94)$ \\
627 & 632 & 627 \\
0.251 & 0.256 & 0.258 \\
\hline
\end{tabular}

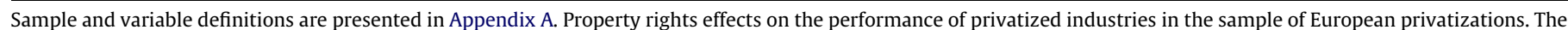

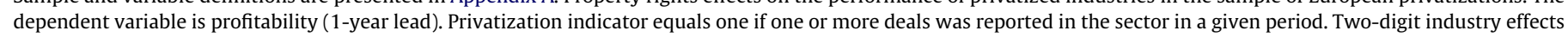
are included. Robust standard errors are in the parentheses.

* Statistical significance at $10 \%$ level.

*** Statistical significance at $1 \%$ level.

** Statistical significance at 5\% level.

claims between counterparties not involving the government and provide enough of an incentive for newly private companies to engage in positive-NPV investment projects and pursuit of growth opportunities. On the other hand, property rights protection from government expropriation could be especially important after privatization since the state is no longer the only claim holder on the firm and private investors are vulnerable to potential rent seeking by the state.

Empirical evidence is presented in Table 1. We draw on earlier work in classifying various country level characteristics into measures of property rights protection, contracting environment, and political institutions.

\subsubsection{Protection of property rights from expropriation}

Our main measure of protection of property rights from expropriation is based on the ICRG index of protection against expropriation by the government, also used in La Porta et al. (1998) and Acemoglu and Johnson (2005), among others. Further, since corruption results in the erosion of the private company's value and cash flows due to rent seeking by government officials, similarly to Fernandes and Kraay (2007), we use control over corruption as a second measure of property rights protection from expropriation. Finally, since an environment with limited rule of law enables unfettered expropriation of private businesses with no recourse for the shareowners, we supplement the control of corruption index with the rule of law index from KKM.

In Panel A, various measures of private property rights protection against government expropriation enter with strongly significant coefficients. The economic importance of the coefficients is commonly assessed by examining the effect of a one-standard deviation change in the explanatory variable on the dependent variable. Holding other factors constant, a one-standard deviation increase (3.6 points on a $0-100$ scale) in the ICRG property rights index is associated with a $1.3 \%$ increase in average profitability. Ceteris paribus, increases by one standard deviation in the corruption control score ( 0.62 points on a -2.5 to 2.5 scale) and in the rule of law score ( 0.37 points on a -2.5 to 2.5 scale) are associated with increases in profitability by $1.7 \%$ and $1.5 \%$, respectively. ${ }^{7} \mathrm{Gi}-$

\footnotetext{
7 Since the ICRG and KKM variables are alternative sources of data on the
} expropriation risk to private property rights, they are included one by one. ven that the average and median profitability are just over $10 \%$, those effects are economically meaningful.

In terms of other controls, large firms have a performance advantage following privatization. Large firms benefit from the economies of scale. Further, consistent with the argument that privatized companies need to procure their own financing through capital markets (Knyazeva et al., 2009), firms characterized by fewer information asymmetries are likely to face fewer financing constraints post-privatization and be more profitable. Growth opportunities enter with insignificant coefficients. Developing economies are associated with higher profitability, consistent with the potential of greater profit generation opportunities as countries catch up to developed markets.

\subsubsection{Contracting and legal environment}

Panel A has focused on the protection of private investors from government expropriation. However, it is possible that the measure is simply capturing the quality of the contracting environment. In earlier work, the quality of contracting institutions has been captured by legal formalism (Acemoglu and Johnson, 2005; Fernandes and Kraay, 2007), defined as the number of legal procedures for collecting on debts or bounced checks or enforcing a contract. A higher number of required legal procedures to enforce contracts suggests more complicated and less investor-friendly legal contracting institutions. The data on the index of formality in legal procedures for collecting on a bounced check is obtained from Djankov et al. (2003) and the data on the number of procedures it takes to enforce a contract is obtained from the Doing Business dataset of the World Bank (since the data starts in 2003 or 2004 for most countries, years prior to the start of reporting use the earliest available value). In addition, we draw on the Gwartney et al. (2011) Economic Freedom of the World (EFW) data on the independence of courts and effectiveness of the legal system and contract enforcement as well as the La Porta et al. (1998) data on the effectiveness of the judicial system.

The results are presented in Panel B. Contracting environment is very important after privatization. In terms of economic magnitude, for instance, a one-standard deviation (0.71) decrease in legal formalism (that boosts contracting rights by easing contract enforcement) has a $1.45 \%$ positive effect on profitability. A decrease in the number of procedures required to enforce a contract 
Table 2

Property rights effects on the performance of privatized sectors: correcting for selection bias.

\begin{tabular}{|c|c|c|c|c|}
\hline & I & II & III & IV \\
\hline \multicolumn{5}{|l|}{ Panel A: Private property rights protection } \\
\hline Property rights & $\begin{array}{l}0.222^{* *} \\
(0.09)\end{array}$ & & & $(0.09)$ \\
\hline Control of corruption & & $\begin{array}{l}2.139^{* * *} \\
(0.51)\end{array}$ & & \\
\hline Rule of law & & & $\begin{array}{l}2.669^{* * *} \\
(0.84)\end{array}$ & \\
\hline Rule of law and corruption control & & & & $\begin{array}{l}2.568^{* * *} \\
(0.65)\end{array}$ \\
\hline Size & $\begin{array}{l}2.006^{* * * *} \\
(0.35)\end{array}$ & $\begin{array}{l}2.023^{* * *} \\
(0.36)\end{array}$ & $\begin{array}{l}1.954^{* * * *} \\
(0.36)\end{array}$ & $\begin{array}{l}1.993^{* * *} \\
(0.36)\end{array}$ \\
\hline Growth opportunities & $\begin{array}{l}-0.201 \\
(1.27)\end{array}$ & $\begin{array}{l}-0.259 \\
(1.28)\end{array}$ & $\begin{array}{l}-0.250 \\
(1.27)\end{array}$ & $\begin{array}{l}-0.255 \\
(1.28)\end{array}$ \\
\hline Economic growth & $\begin{array}{l}-0.108 \\
(0.18)\end{array}$ & $\begin{array}{l}-0.144 \\
(0.19)\end{array}$ & $\begin{array}{l}-0.102 \\
(0.18)\end{array}$ & $\begin{array}{l}-0.133 \\
(0.19)\end{array}$ \\
\hline Income per capita & $\begin{array}{l}-9.380^{* * * *} \\
(1.02)\end{array}$ & $\begin{array}{l}-9.930^{* * *} \\
(1.03)\end{array}$ & $\begin{array}{l}-9.489^{* * *} \\
(1.02)\end{array}$ & $\begin{array}{l}-9.880^{* * *} \\
(1.03)\end{array}$ \\
\hline Obs. & 8834 & 8829 & 8829 & 8829 \\
\hline \multirow[t]{2}{*}{ Wald test of independence of equations (Ho: independent) } & $26.50^{* * * *}$ & $23.24 \mathrm{v}$ & $23.79^{* * * *}$ & $22.82^{* * *}$ \\
\hline & $\mathrm{V}$ & VI & VII & VIII \\
\hline Property rights & $0.174^{* *}$ & & & \\
\hline Control of corruption & & $\begin{array}{l}1.451^{* * * *} \\
(0.52)\end{array}$ & & \\
\hline Rule of law & & & $\begin{array}{l}1.399^{*} \\
(0.84)\end{array}$ & \\
\hline Rule of law and corruption control & & & & $\begin{array}{l}1.633^{* *} \\
(0.66)\end{array}$ \\
\hline Legal formalism & $\begin{array}{l}-1.689^{* * *} \\
(0.41)\end{array}$ & $\begin{array}{l}-1.406^{* * *} \\
(0.42)\end{array}$ & $\begin{array}{l}-1.585^{* * *} \\
(0.42)\end{array}$ & $\begin{array}{l}-1.452^{* * *} \\
(0.42)\end{array}$ \\
\hline Size & $\begin{array}{l}2.087^{* * * *} \\
(0.37)\end{array}$ & $\begin{array}{l}2.107^{* * *} \\
(0.38)\end{array}$ & $\begin{array}{l}2.080^{* * *} \\
(0.38)\end{array}$ & $\begin{array}{l}2.092^{* * *} \\
(0.38)\end{array}$ \\
\hline Growth opportunities & $\begin{array}{l}-0.383 \\
(1.28)\end{array}$ & $\begin{array}{l}-0.408 \\
(1.28)\end{array}$ & $\begin{array}{l}-0.420 \\
(1.27)\end{array}$ & $\begin{array}{l}-0.409 \\
(1.28)\end{array}$ \\
\hline Economic growth & $\begin{array}{l}-0.088 \\
(0.18)\end{array}$ & $\begin{array}{l}-0.100 \\
(0.19)\end{array}$ & $\begin{array}{l}-0.060 \\
(0.19)\end{array}$ & $\begin{array}{l}-0.089 \\
(0.19)\end{array}$ \\
\hline Income per capita & $\begin{array}{l}-10.562^{* * *} \\
(1.06)\end{array}$ & $\begin{array}{l}-10.524^{* * *} \\
(1.07)\end{array}$ & $\begin{array}{l}-10.128^{* * *} \\
(1.06)\end{array}$ & $\begin{array}{l}-10.439^{* * *} \\
(1.07)\end{array}$ \\
\hline $\begin{array}{l}\text { Obs. } \\
\text { Wald test of independence of equations (Ho: independent) }\end{array}$ & $\begin{array}{l}8830 \\
23.67^{* * *}\end{array}$ & $\begin{array}{l}8825 \\
22.67^{* * * *}\end{array}$ & $\begin{array}{l}8825 \\
24.76^{* * *}\end{array}$ & $\begin{array}{l}8825 \\
22.99^{* * *}\end{array}$ \\
\hline
\end{tabular}

Panel B: Contracting institutions and legal system

Legal formalism

\section{$-1.819^{* * * *}$}

$(0.41)$

Difficulty of enforcing contracts (procedures)

Difficulty of enforcing contracts (days)

Effectiveness of the judicial system

Courts

Legal system

Legal system and contract enforcement

Size

Growth opportunities

Economic growth

Income per capita

Obs.

Wald test of independence of equations (Ho: independent)

Panel C. Political system and government effectiveness

Constraint on the executive

$$
\begin{aligned}
& -0.153^{* * *} \\
& (0.06)
\end{aligned}
$$$$
-0.004^{* * * *}
$$$$
(0.0)
$$$$
1.837^{* * *}
$$$$
\text { (0.29) }
$$$$
0.618^{* * *}
$$$$
(0.20)
$$

$0.564^{* *}$

$(0.23)$

$\begin{array}{lll} & (0.23) & \begin{array}{l}0.608^{* * * *} \\ (0.22)\end{array} \\ & & 2.455^{* * *} \\ 2.466^{* * *} & 2.470^{* * * *} & (0.39) \\ (0.39) & (0.39) & -0.469 \\ -0.472 & -0.480 & (1.35) \\ (1.33) & (1.35) & -0.245 \\ -0.263 & -0.216 & (0.21) \\ (0.22) & (0.21) & -10.035^{* * *} \\ -10.324^{* * *} & -10.110^{* * *} & (1.0) \\ (1.06) & (1.03) & 8752 \\ 8752 & 8752 & 37.67^{* * *} \\ 39.54^{* * *} & 39.17 & \end{array}$


Voice and accountability

Limited government

Government effectiveness

Regulatory quality

Regulations

Political stability

Size

Growth opportunities

Economic growth

Income per capita

Obs.

Wald test of independence of equations (Ho: independent)
$-2.167$

(1.57)

0.261

$(0.25)$
$2.544^{* * *}$
$(0.69)$

$-0.011$

(1.13)
$0.878^{* * *}$
$(0.34)$

0.049

(1.05)

$1.992^{* * * *}$

$(0.36)$

$-0.261$

(1.25)

$-0.031$

(0.18)

$-7.963^{* * *}$

(0.93)

8829 $27.89^{* * * *}$

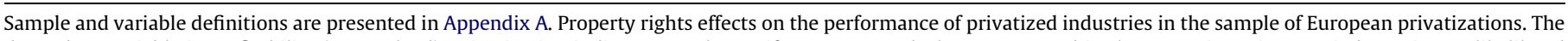

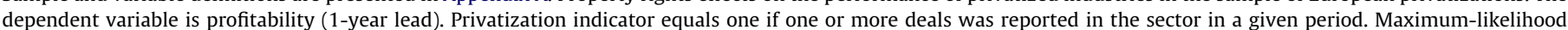

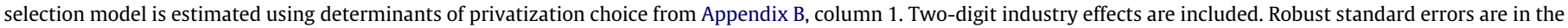
parentheses.

${ }_{* * *}$ Statistical significance at $1 \%$ level.

** Statistical significance at 5\% level.

* Statistical significance at $10 \%$ level.

by one standard deviation ( 4.9 procedures) has a $0.7 \%$ positive effect on profitability, all else equal.

Moreover, the strength of contracting institutions has additional importance for predicting post-privatization performance when introduced into the specifications examining private property rights protection from expropriation in Panel A. Indeed, while private investors must be concerned about government rent seeking with respect to enterprises that are no longer under (full) government control, since they now also have to interact with private counterparties on contractual claims, the quality of the contracting and legal institutions is also important.

\subsubsection{General quality of political institutions and constraint on the executive}

Finally, in Panel C we turn our attention to supplementary measures that might be less related to expropriation but rather capture the overall risk of political instability and the quality of political institutions and democracy in the country. We use KKM political stability, government effectiveness, voice and accountability, and broad regulatory quality scores, and following Acemoglu and Johnson (2005), the Polity IV index of the extent of constraints on the executive. Although political stability and government effectiveness have a generally favorable effect, most political institutions measures do not come in significantly. Specificity of the benefits to the profitability after privatization from greater protection of private investors against expropriation and better enforcement of contractual rights is far more consistent with our main hypothesis than the general effects of political institutions.

\subsubsection{Accounting for the non-random selection into the privatization group}

Given the conceptual importance of selection concerns, we repeat the estimation of property rights effects on post-privatization performance using a selection model, which was described in Section 3. Estimates are summarized in Table 2 . The Wald test strongly rejects the null hypothesis of independence of selection and prof- itability equations, confirming our intuition about the need to account for non-random selection into the privatization sample.

However, encouragingly, we observe that the main property rights result is corroborated after correction for selection. The effects remain statistically and economically significant for all measures of private property rights protection against expropriation as well as all measures of contracting rights and legal environment. The general quality of political institutions, limited government and democracy does not appear to be relevant for post-privatization performance (the government effectiveness score retains its significance).

Other controls enter with consistent coefficients. Some property rights coefficients enter with lower magnitudes, possibly due to the fact that better pre-privatization performance, intuitively associated with strong property rights, predicts selection into the privatization according to the first stage model estimates in Appendix B. However, though selection bias is present and it is important to address it, the general direction of the property rights and contracting rights effects is preserved, providing support for our main hypothesis.

\subsubsection{Robustness tests}

We have already considered additional controls, as well as industry effects, and several different property rights measures in Tables 1 and 2. Further robustness checks are shown in Appendix C. Models with correction for selection used fewer observations for the treatment (privatization) sample than ordinary least squares due to missing observations on privatization determinants. To ensure that differences in sample coverage are not skewing our interpretation of the results, we repeat ordinary least squares estimates of the main specification, contained in Column I of Table 1, after excluding observations with missing determinants data. The results are similar (Column I). Since financial firms are likely to be subject to different regulatory treatment and have different debt usage patterns, they are often excluded in empirical corporate finance analysis. Exclusion of financials does not qualitatively change the results (Column II). The control for the proportion of 
public offer deals (as opposed to privately negotiated sales), added in Column III, does not enter significantly, and it does not affect the significance of the property rights coefficients. For robustness we also reproduce the main test in the SDC sample, which includes non-European as well as European privatizations, in Column IV, and arrive at similar estimates. Thus, based on the evidence presented above, property rights are essential for realizing strong post-privatization operating performance. The effect continues to hold across multiple property rights metrics and after accounting for selection bias.

\subsubsection{Acquirer effects on the performance of privatized industries}

Next, we ask whether property rights in the buyer's country have incremental significance for post-privatization performance of the industry undergoing the privatization reform. To the extent that the buyer is expected to actively partake in restructuring the privatized enterprise, and buyer's incentives to restructure and set up improved monitoring mechanisms within the privatized enterprise are affected by the buyer's own property rights environment, then we can observe significant spillovers of buyer property rights protection on privatization outcomes. The empirical evidence is presented in Table 3.

In Columns I-III, the quality of overall acquirer property rights, as well as individual dimensions of private property rights protection from expropriation in the buyer's country, such as control of corruption and rule of law, have a positive effect on post-privatization performance in the privatization sample, consistent with the latter conjecture. The effect of interest remains significant when additional controls are introduced in Columns IV-VII. Further, the effect continues to hold when we restrict our attention to the subsample of cross-border deals only (Columns VI-VII) or correct for selection bias (Column VIII). Control coefficients are not surprising. Larger firms continue to perform better. The biggest profit opportunities are found in developing countries. Less competitive industries are associated with wider profit margins. Cross-border privatizations perform worse, consistent with monitoring costs of distance. Proxies for how extensive privatization reforms are, based on logged number and relative value of privatization deals, are inconclusive, as is the diversification indicator coefficient. Thus, the property rights environment in the buyer's country appears to be important for assuring operating performance improvement in the privatizing sector following privatization, consistent with our prediction.

\subsection{Privatization and property rights effects on performance}

We have so far focused on the effects of property rights and legal and political environment characteristics on the performance in the privatization group. Tests of the privatization and institutional environment effects on profitability in the full sample, which includes both cases of privatizations and government ownership, are shown in Table 4. Panel A uses the ICRG measure of property rights. The effect of property rights, shown in Tables 1 and 2 to be meaningful for post-privatization performance, remains significant in the full sample of sectors. All else equal, a one-standard deviation increase in the ICRG index is associated with a $0.8-$ $0.9 \%$ increase in profitability.

Larger firms are associated with better performance. The most lucrative profit generation opportunities are present in emerging economies, even within the European sample, as confirmed by the negative effect of GDP per capita, our macro level proxy for the level of economic development. Additional controls are contained in Columns II-III. Industries with less competition are on average more profitable, consistent with the intuition about monopolies versus perfectly competitive markets. It is an important reminder that "success" in terms of private profitability does not necessarily correspond to an increase in social welfare: the increased profitability of a privatized monopoly may only be a consequence of its greater willingness to exploit consumers, not because of enhanced efficiency. After controlling for other determinants,

Table 3

Acquirer property rights effects on the performance in privatized sectors.

\begin{tabular}{|c|c|c|c|c|c|c|c|c|}
\hline & I & II & III & IV & $\mathrm{V}$ & VI & VII & VIII \\
\hline Acquirer property rights quality & $\begin{array}{l}1.444^{\text {**** }} \\
(.51)\end{array}$ & & & $\begin{array}{l}1.886^{* * * *} \\
(.56)\end{array}$ & $\begin{array}{l}1.900^{* * * *} \\
(.55)\end{array}$ & $\begin{array}{l}1.573^{* *} \\
(.77)\end{array}$ & $\begin{array}{l}1.541^{* *} \\
(.76)\end{array}$ & $\begin{array}{l}2.393^{* * * *} \\
(.85)\end{array}$ \\
\hline Acquirer control of corruption & & $\begin{array}{l}1.074^{* * *} \\
(.38)\end{array}$ & & & & & & \\
\hline Acquirer rule of law & & & $\begin{array}{l}1.278^{* * * *} \\
(.46)\end{array}$ & & & & & \\
\hline Size & $\begin{array}{l}1.622^{* * *} \\
(.29)\end{array}$ & $\begin{array}{l}1.601^{* * *} \\
(.28)\end{array}$ & $\begin{array}{l}1.616^{* * * *} \\
(.29)\end{array}$ & $\begin{array}{l}1.589^{* * * *} \\
(.28)\end{array}$ & $\begin{array}{l}1.590^{* * *} \\
(.28)\end{array}$ & $\begin{array}{l}1.745^{\text {**** }} \\
(.46)\end{array}$ & $\begin{array}{l}1.605^{* * *} \\
(.46)\end{array}$ & $\begin{array}{l}2.944^{* * * *} \\
(.44)\end{array}$ \\
\hline Growth opportunities & $\begin{array}{l}0.419 \\
(.48)\end{array}$ & $\begin{array}{l}0.430 \\
(.48)\end{array}$ & $\begin{array}{l}0.401 \\
(.49)\end{array}$ & $\begin{array}{l}0.309 \\
(.49)\end{array}$ & $\begin{array}{l}0.384 \\
(.48)\end{array}$ & $\begin{array}{l}0.279 \\
(.92)\end{array}$ & $\begin{array}{l}0.536 \\
(.90)\end{array}$ & $\begin{array}{l}0.241 \\
(.62)\end{array}$ \\
\hline Crossborder deals & & & & $\begin{array}{l}-1.717^{* *} \\
(.81)\end{array}$ & $\begin{array}{l}-1.931^{* *} \\
(.81)\end{array}$ & $\begin{array}{l}-2.383 \\
(1.48)\end{array}$ & $\begin{array}{l}-4.953^{* * * *} \\
(1.70)\end{array}$ & \\
\hline Diversifying deals & & & & $\begin{array}{l}-0.389 \\
(.80)\end{array}$ & $\begin{array}{l}-0.331 \\
(.79)\end{array}$ & & $\begin{array}{l}0.077 \\
(1.35)\end{array}$ & \\
\hline Privatization deals & & & & & $\begin{array}{l}-0.895 \\
(.91)\end{array}$ & & $\begin{array}{l}-2.890^{*} \\
(1.48)\end{array}$ & \\
\hline Privatization value & & & & & $\begin{array}{l}-0.238^{*} \\
(.13)\end{array}$ & & $\begin{array}{l}-0.204 \\
(.16)\end{array}$ & \\
\hline Industry concentration & & & & & $\begin{array}{l}3.574^{* * *} \\
(1.12)\end{array}$ & & $\begin{array}{l}3.801^{* *} \\
(1.70)\end{array}$ & \\
\hline Income per capita & $\begin{array}{l}-2.282^{* * * *} \\
(.38)\end{array}$ & $\begin{array}{l}-2.227^{* * *} \\
(.36)\end{array}$ & $\begin{array}{l}-2.230^{* * * *} \\
(.37)\end{array}$ & $\begin{array}{l}-2.523^{* * *} \\
(.41)\end{array}$ & $\begin{array}{l}-2.666^{* * *} \\
(.42)\end{array}$ & $\begin{array}{l}-2.578^{* * * *} \\
(.54)\end{array}$ & $\begin{array}{l}-2.727^{* * *} \\
(.58)\end{array}$ & $\begin{array}{l}-3.440^{* * * *} \\
(.72)\end{array}$ \\
\hline Obs. & 704 & 704 & 704 & 704 & 704 & 314 & 314 & 17,859 \\
\hline$R^{2}$ & 0.27 & 0.27 & 0.27 & 0.28 & 0.30 & 0.33 & 0.36 & \\
\hline
\end{tabular}

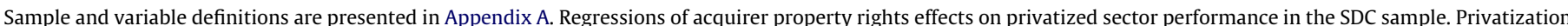

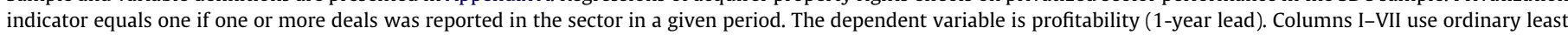

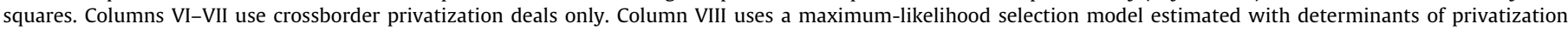
choice from Appendix B, column 1. Two-digit industry effects are included. Robust standard errors are in the parentheses.

**** Statistical significance at $1 \%$ level.

** Statistical significance at 5\% level.

* Statistical significance at $10 \%$ level. 
Table 4

Privatization and property rights effects on performance (all sectors).

\begin{tabular}{|c|c|c|c|c|}
\hline & \multicolumn{2}{|l|}{$\mathrm{I}$} & II & III \\
\hline $\begin{array}{l}\text { Panel A: Main tests } \\
\text { Privatization }\end{array}$ & \multicolumn{2}{|l|}{$\begin{array}{l}0.214 \\
(.29)\end{array}$} & $\begin{array}{l}-1.206 \\
(.87)\end{array}$ & $\begin{array}{l}-0.917 \\
(.86)\end{array}$ \\
\hline Property rights & \multicolumn{2}{|c|}{$\begin{array}{l}0.236^{* * *} \\
(.03)\end{array}$} & $\begin{array}{l}0.236^{* * * *} \\
(.03)\end{array}$ & $\begin{array}{l}0.206^{* * *} \\
(.03)\end{array}$ \\
\hline Size & \multirow{2}{*}{\multicolumn{2}{|c|}{$\begin{array}{l}1.116^{* * *} \\
(.09) \\
-0.367 \\
(.24)\end{array}$}} & $\begin{array}{l}1.118^{* * *} \\
(.09)\end{array}$ & $\begin{array}{l}1.148^{* * * *} \\
(.09)\end{array}$ \\
\hline Growth opportunities & & & $\begin{array}{l}-0.371 \\
(.24)\end{array}$ & $\begin{array}{l}-0.324 \\
(.24)\end{array}$ \\
\hline Privatization deals & & & $(.39)$ & $\begin{array}{l}0.365 \\
(.39)\end{array}$ \\
\hline Privatization stake & & & $\begin{array}{l}0.010 \\
(.01)\end{array}$ & $\begin{array}{l}0.009 \\
(.01)\end{array}$ \\
\hline \multicolumn{4}{|l|}{ Privatization value } & $\begin{array}{l}0.06^{* *} \\
(.02)\end{array}$ \\
\hline \multicolumn{4}{|l|}{ Industry concentration } & $\begin{array}{l}1.832^{* * * *} \\
(.28)\end{array}$ \\
\hline Income per capita & \multicolumn{2}{|c|}{$\begin{array}{l}-4.375^{* * *} \\
(.26)\end{array}$} & $\begin{array}{l}-4.387^{* * *} \\
(.26)\end{array}$ & $\begin{array}{l}-4.008^{* * * *} \\
(.27)\end{array}$ \\
\hline \multirow[t]{2}{*}{$\begin{array}{l}\text { Obs. } \\
R^{2}\end{array}$} & \multicolumn{2}{|c|}{$\begin{array}{l}10,746 \\
0.16\end{array}$} & $\begin{array}{l}10,746 \\
0.16\end{array}$ & $\begin{array}{l}10,746 \\
0.16\end{array}$ \\
\hline & $\mathrm{I}$ & II & III & IV \\
\hline \multicolumn{5}{|c|}{ Panel B: Other property rights risk measures } \\
\hline Privatization & $\begin{array}{l}0.167 \\
(.29)\end{array}$ & $\begin{array}{l}0.065 \\
(.29)\end{array}$ & $\begin{array}{l}0.126 \\
(.29)\end{array}$ & $\begin{array}{l}0.181 \\
(.29)\end{array}$ \\
\hline Property rights quality & $\begin{array}{l}3.698^{* * * *} \\
(.28)\end{array}$ & & & \\
\hline Control of corruption & & $\begin{array}{l}1.937^{* * *} \\
(.15)\end{array}$ & & \\
\hline Rule of law & & & $\begin{array}{l}3.028^{* * *} \\
(.23)\end{array}$ & \\
\hline Political stability & & & & $\begin{array}{l}2.984^{* * *} \\
(.26)\end{array}$ \\
\hline Size & $\begin{array}{l}1.118^{* * *} \\
(.09)\end{array}$ & $\begin{array}{l}1.076^{* * *} \\
(.09)\end{array}$ & $\begin{array}{l}1.081^{* * *} \\
(.09)\end{array}$ & $\begin{array}{l}1.152^{* * *} \\
(.09)\end{array}$ \\
\hline Growth opportunities & $\begin{array}{l}-0.390 \\
(.24)\end{array}$ & $\begin{array}{l}-0.410^{*} \\
(.24)\end{array}$ & $\begin{array}{l}-0.413^{*} \\
(.24)\end{array}$ & $\begin{array}{l}-0.319 \\
(.24)\end{array}$ \\
\hline Income per capita & $\begin{array}{l}-5.020^{* * *} \\
(.25)\end{array}$ & $\begin{array}{l}-4.811^{* * * *} \\
(.25)\end{array}$ & $\begin{array}{l}-4.864^{* * *} \\
(.25)\end{array}$ & $\begin{array}{l}-3.751^{* * * *} \\
(.22)\end{array}$ \\
\hline Obs. & 10,718 & 10,718 & 10,718 & 10,718 \\
\hline$R^{2}$ & 0.16 & 0.16 & 0.16 & 0.16 \\
\hline
\end{tabular}

Sample and variable definitions are presented in Appendix A. Regressions of privatization and property rights effects on performance in the European sample of all (privatized and public) sectors. The dependent variable is profitability (1-year lead). Privatization indicator equals one if one or more deals was reported in the sector in a given period. Two-digit industry effects are included. Robust standard errors are in the parentheses.

**** Statistical significance at $1 \%$ level.

** Statistical significance at 5\% level.

Statistical significance at $10 \%$ level.

growth opportunities do not enter significantly. Privatization scale controls yield ambiguous evidence - deal count and average stake are not significant, while privatization deal value relative to industry assets has a positive sign.

Panel B replicates the main test using other measures of property rights quality. The overall index of property rights quality based on KKM has a significant positive relation to operating performance. An increase by 1 in the property rights quality index, which varies between -2.5 and 2.5 , is associated with a $3.7 \%$ increase in average profitability in the sector, all else equal (Column I). Individual property rights determinants have significant positive effects in Columns II-IV. Their economic effects are also meaningful and range from $1 \%$ to $1.3 \%$ for a one-standard deviation increase in the KKM measure.

In the OLS specification, the effect of privatization itself is not significant.
Table 5

Privatization and property rights effects on performance (all sectors): accounting for the choice of privatization

\begin{tabular}{lllll}
\hline & I & II & III & IV \\
\hline Privatization & $-12.332^{* * *}$ & $-12.357^{* * *}$ & $-20.126^{* * *}$ & $-27.482^{* * *}$ \\
& $(.55)$ & $(.56)$ & $(3.88)$ & $(4.11)$ \\
Property rights & $0.262^{* * *}$ & & $0.289^{* * *}$ & \\
Property rights & $(.03)$ & & $(.04)$ & $3.908^{* * *}$ \\
$\quad$ & & $3.256^{* * *}$ & & \\
quality & & $(.33)$ & & $(.46)$ \\
Size & $1.299^{* * *}$ & $1.301^{* * *}$ & $1.302^{* * *}$ & $1.382^{* * *}$ \\
Growth opportunities & $(.10)$ & $(.10)$ & $(.11)$ & $(.11)$ \\
& $-0.557^{* *}$ & $-0.567^{* *}$ & -0.268 & -0.160 \\
Income per capita & $(.29)$ & $(.29)$ & $(.36)$ & $(.39)$ \\
& $-7.110^{* * *}$ & $-7.168^{* * *}$ & $-9.206^{* * *}$ & $-10.322^{* * *}$ \\
Obs. & $(.42)$ & $(.42)$ & $(.61)$ & $(.71)$ \\
\hline
\end{tabular}

Sample and variable definitions are presented in Appendix A. Regressions of privatization and property rights effects on performance in the European sample of all (privatized and public) sectors. The dependent variable is profitability (1-year lead). Columns I and II use treatment effects estimation. Columns III and IV use instrumental variables estimation. Privatization indicator equals one if one or more deals were reported in the sector in a given period. Two-digit industry effects are included. Privatization is predicted with the first-stage determinants in Table C1. Robust standard errors are in the parentheses.

*** Statistical significance at $1 \%$ level.

** Statistical significance at $5 \%$ level.

Statistical significance at $10 \%$ level.

We account for the choice of privatization in Table 5 using the model of privatization determinants from Appendix B. The privatization coefficient estimate changes from statistically insignificant to negative and significant. The effect is economically important and represents a reversal from ordinary least squares results. Consistent with the finding in Appendix B, governments in the sample on average privatize better performing sectors. Correcting for this non-causal positive effect should lead to a decrease in the privatization coefficient estimate, and we note it becomes negative. This result does not suggest that private ownership is inherently inefficient or value destroying or that privatized sectors post losses. (As can be seen from the summary statistics in Appendix A, the average profitability in the privatization group was significantly positive (above $10 \%$ of assets on average).) This test merely provides a multivariate comparison of privatization and non-privatization groups and suggests that the privatization process may pose tradeoffs that have the effect of lowering profitability in relative terms, compared to other enterprises, at least over a short horizon. Intuitively, it takes time for the newly private firm to recoup direct costs of restructuring and to respond to decreases or elimination of subsidies previously directed to the firm under state ownership as well as new intra-firm conflicts and/or government expropriation risks. ${ }^{8}$

The property rights environment retains its significance as a determinant of performance. ${ }^{9}$

\footnotetext{
8 The effects of increased expropriation risks and of reduced subsidization by the government of newly privatized firms that are no longer under state ownership combined have the effect of limiting post-privatization profitability in the short term. We evaluate this hypothesis as well as the horizon of the privatization effect on profitability in more detail in Table 6 .

${ }^{9}$ In untabulated tests, we find that strong protections from expropriation and corruption, greater government effectiveness and a higher level of political stability are also associated with better performance of public sectors. Intuitively, deadweight costs of asset stripping and government rent-seeking are likely to be lower when corruption is better controlled and governments are more effective. As a result, performance should be better even under state ownership. The positive effects of property rights in the both privatization and public groups combine to yield a positive overall effect of property rights on performance.
} 
Several additional robustness tests are presented in Appendix C. Observations with missing data on privatization determinants are excluded in Column I, to assure sample consistency between ordinary least squares and endogeneity correction tests and to avoid attributing differences in privatization effect estimates to different sample coverage. Financial sector observations are excluded in Column II and additional controls are considered in Column III. Consistent with the industrial organization literature, profitability tends to be higher in more concentrated industries. Privatizations involving larger average stakes and public offers as opposed to privately negotiated sales perform marginally better. Use of the SDC sample, which includes countries outside Europe, in place of the Privatization Barometer sample, in Columns IV-V yields findings that are highly similar to the analysis of the main sample in Tables 3 and 4. In untabulated tests, repeating the analysis using profitability changes yields similar results.

An important question in the context of our argument is the extent of persistence of the privatization effects. Indeed, it is important to know if the downside from privatization tradeoffs is eventually eliminated and how soon that occurs for a typical privatization reform. We examine this question in Table 6.

Table 6

Variation in privatization effects on performance and their persistence.

\begin{tabular}{|c|c|c|}
\hline & $\begin{array}{l}\text { High (above median) } \\
\text { reliance on subsidies } \\
\text { prior to privatization }\end{array}$ & $\begin{array}{l}\text { Low (below median) } \\
\text { reliance on subsidies } \\
\text { prior to privatization }\end{array}$ \\
\hline$t+1$ & $\begin{array}{l}-7.974^{* * *} \\
(1.59)\end{array}$ & $\begin{array}{l}8.105^{\text {**** }} \\
(1.88)\end{array}$ \\
\hline$t+2$ & $\begin{array}{l}-7.531^{* * *} \\
(1.24)\end{array}$ & $\begin{array}{l}7.298^{* * *} \\
(2.28)\end{array}$ \\
\hline$t+3$ & $\begin{array}{l}-8.266^{* * *} \\
(1.51)\end{array}$ & $\begin{array}{l}7.132^{\text {**** }} \\
(2.16)\end{array}$ \\
\hline$t+4$ & $\begin{array}{l}-8.605^{\text {*** }} \\
(1.50)\end{array}$ & $\begin{array}{l}6.875^{* * *} \\
(2.23)\end{array}$ \\
\hline$t+5$ & $\begin{array}{l}-9.096^{* * *} \\
(1.43)\end{array}$ & $\begin{array}{l}6.242^{\text {**** }} \\
(2.06)\end{array}$ \\
\hline$t+6$ & $\begin{array}{l}-8.995^{* * *} \\
(1.66)\end{array}$ & $\begin{array}{l}5.652^{\text {*** }} \\
(2.03)\end{array}$ \\
\hline$t+7$ & $\begin{array}{l}-7.940^{* * * *} \\
(1.03)\end{array}$ & $\begin{array}{l}4.588^{* *} \\
(1.87)\end{array}$ \\
\hline$t+8$ & $\begin{array}{l}-7.565^{* * *} \\
(1.23)\end{array}$ & $\begin{array}{l}3.835^{* *} \\
(1.81)\end{array}$ \\
\hline$t+9$ & $\begin{array}{l}-7.857^{* * *} \\
(1.24)\end{array}$ & $\begin{array}{l}2.180 \\
(1.64)\end{array}$ \\
\hline$t+10$ & $\begin{array}{l}-7.475^{* * *} \\
(1.79)\end{array}$ & $\begin{array}{l}2.326 \\
(1.44)\end{array}$ \\
\hline$t+11$ & $\begin{array}{l}-5.394 \\
(3.71)\end{array}$ & $\begin{array}{l}1.089 \\
(1.60)\end{array}$ \\
\hline$t+12$ & $\begin{array}{l}-4.170 \\
(3.90)\end{array}$ & $\begin{array}{l}2.580^{* *} \\
(1.23)\end{array}$ \\
\hline$t+13$ & $\begin{array}{l}-2.879 \\
(4.08)\end{array}$ & $\begin{array}{l}3.500^{* * * *} \\
(1.36)\end{array}$ \\
\hline$t+14$ & $\begin{array}{l}-1.045 \\
(1.67)\end{array}$ & $\begin{array}{l}4.554^{* *} \\
(1.90)\end{array}$ \\
\hline$t+15$ & $\begin{array}{l}-0.802 \\
(1.39)\end{array}$ & $\begin{array}{l}-0.214 \\
(2.62)\end{array}$ \\
\hline
\end{tabular}

Sample and variable definitions are presented in Appendix A. Regressions of privatization and property rights effects on performance in the European sample of all (privatized and public) sectors. The dependent variable is profitability (in years $t+1$ through $t+15$ ). Treatment effects estimation. Privatization indicator equals one in year after the conclusion of privatization. Two-digit industry effects are included. Privatization is predicted with the first-stage determinants in Appendix B, columns 1 , and the pre-privatization index of SOE presence in the economy from Gwartney et al. (2011). Control for profitability in the year preceding the start of privatization is added; its omission does not affect the result. The data on subsidies is obtained from EFW. The sample for this test excludes countries in the top quartile of private ownership prior to privatization based on La Porta et al. (2002) measure of SOEs in the economy. Robust standard errors are in the parentheses.

* Statistical significance at $10 \%$ level.

* Statistical significance at $1 \%$ level.

** Statistical significance at $5 \%$ level.
Privatization is traditionally associated with the elimination of soft budget constraints across the board. In some cases heavy government subsidization of state-owned enterprises could have aided their profitability, whereas they would have to improve efficiency, which takes time, to sustain such performance independently. Therefore, we condition the test on variation in the extent of subsidization prior to privatization. In cases of greater pre-privatization reliance on the government for subsidies and transfers prior to privatization, the short- and medium-run effects of privatization are negative, consistent with the newly private enterprises struggling to achieve profitability after subsidies are removed. However, the effect is mitigated in the long run as the necessary efficiency improvements are implemented.

Thus, consistent with what one might expect, privatization effects grow weaker and become insignificant in the long run (10 years since the reform completion), corroborating the notion that the tradeoffs are felt more acutely in the short to medium term. With the passage of time, companies are able to leverage the incentive improvements associated with the switch to private ownership and compensate for the costs of restructuring.

By comparison, in cases where the government did not subsidize heavily prior to privatization, newly privatized firms do not experience the adverse shock of subsidy reduction and instead appear to benefit right away from a switch to private ownership through privatization.

The results of Tables 3-6 yield several conclusions. The traditional evidence on the effects of privatization is likely confounded by the non-random nature of privatization decisions, with better performers more likely to be privatized, all else equal. Accounting for the choice of privatization in an attempt to identify a causal relation between privatization and performance lowers the observed privatization estimate and renders it negative, supporting the need to recognize the short-term costs of privatization that weigh on profitability as well as its long-term benefits from improvement in incentives. The challenges to sustaining profitability for newly privatized enterprises are most pronounced when there is heavy reliance on government subsidies prior to privatization (lowered post-privatization). Although the effect is strong in the short run, it disappears in the long run (or at least becomes statistically insignificant, though the coefficient remains negative). While this evidence updates conventional wisdom about privatization, it is important to note its context and timing and recognize that it represents a relative comparison with the non-privatization group and that average profitability remains positive in the privatization group.

\subsubsection{Telecom study}

Appendix D (Panel B) reports univariate tests of differences in operating efficiency for privatized and state-owned subsamples. Without controlling for other determinants, operating efficiency levels have improved over time in both privatization and government-owned samples, by 93.7 and 53.4 lines per employee, respectively, with the privatization sample posting a better overall improvement in levels of output per employee. When we look at rates of change in operating efficiency, while both samples exhibit increases in the rate of change in efficiency, they are not significantly different from zero, nor is the difference due to privatization statistically significant. Thus, univariate evidence is not conclusive.

Table 7, Panel A reports the effects of various determinants of performance changes around telecom privatizations after correcting for selection into the privatization subsample. ${ }^{10}$ Tests within the telecom privatization sample corroborate the property rights finding obtained in the main sample. Good institutional quality con-

10 Test statistics, corroborate our concern about selection bias. 
Table 7

Telecom sector study.

\begin{tabular}{|c|c|c|c|}
\hline & I & II & III \\
\hline \multicolumn{4}{|c|}{ Panel A: Property rights effects on performance of privatized sectors } \\
\hline Property rights & $\begin{array}{l}0.336^{* * * *} \\
(.12)\end{array}$ & $\begin{array}{l}0.388^{* *} \\
(.16)\end{array}$ & $\begin{array}{l}0.396^{* *} \\
(.16)\end{array}$ \\
\hline \multicolumn{2}{|l|}{ French legal origin } & & $\begin{array}{l}1.249 \\
(2.87)\end{array}$ \\
\hline Regulator (prior) & $\begin{array}{l}4.508^{* *} \\
(2.18)\end{array}$ & $\begin{array}{l}4.342^{* *} \\
(2.14)\end{array}$ & $\begin{array}{l}4.394^{* *} \\
(2.14)\end{array}$ \\
\hline Domestic bank credit & $\begin{array}{l}0.053 \\
(.05)\end{array}$ & $\begin{array}{l}0.050 \\
(.05)\end{array}$ & $\begin{array}{l}0.050 \\
(.06)\end{array}$ \\
\hline Ethno-linguistic fractionalization & $\begin{array}{l}-19.810^{* *} \\
(8.00)\end{array}$ & $\begin{array}{l}-18.615^{* *} \\
(8.50)\end{array}$ & $\begin{array}{l}-17.699^{* *} \\
(8.37)\end{array}$ \\
\hline Life expectancy & $\begin{array}{l}-0.470 \\
(.38)\end{array}$ & $\begin{array}{l}-0.396 \\
(.40)\end{array}$ & $\begin{array}{l}-0.359 \\
(.39)\end{array}$ \\
\hline GNP per capita (logged) & $\begin{array}{l}-8.526^{* * *} \\
(2.03)\end{array}$ & $\begin{array}{l}-8.485^{* * * *} \\
(2.02)\end{array}$ & $\begin{array}{l}-8.415^{* * * *} \\
(2.04)\end{array}$ \\
\hline Main lines (prior) & & $\begin{array}{l}-0.007 \\
(.01)\end{array}$ & $\begin{array}{l}-0.007 \\
(.02)\end{array}$ \\
\hline Sub-Saharan Africa & $\begin{array}{l}-15.914^{* * *} \\
(4.52)\end{array}$ & $\begin{array}{l}-15.759^{* * * *} \\
(4.51)\end{array}$ & $\begin{array}{l}-15.602^{* * *} \\
(4.58)\end{array}$ \\
\hline \multirow[t]{2}{*}{ Obs. } & 62 & 62 & 62 \\
\hline & I & & II \\
\hline \multicolumn{4}{|c|}{ Panel B. Privatization effects on performance } \\
\hline Privatization & \multicolumn{2}{|c|}{$\begin{array}{l}-13.080^{* * *} \\
(4.04)\end{array}$} & $\begin{array}{l}-13.093^{* * *} \\
(4.04)\end{array}$ \\
\hline Property rights & \multicolumn{2}{|c|}{-0.051} & $\begin{array}{l}-0.079 \\
(.22)\end{array}$ \\
\hline Budget balance & \multicolumn{2}{|c|}{$-0.684^{*}$} & $\begin{array}{l}-0.682^{*} \\
(.36)\end{array}$ \\
\hline Regulatory reform & \multicolumn{2}{|c|}{$\begin{array}{l}6.291 \\
(4.50)\end{array}$} & $\begin{array}{l}6.302 \\
(4.50)\end{array}$ \\
\hline Ethno-linguistic fractionalization & \multicolumn{2}{|c|}{$\begin{array}{l}-14.722 \\
(8.24)\end{array}$} & $\begin{array}{l}-14.641^{*} \\
(8.25)\end{array}$ \\
\hline Life expectancy & \multicolumn{2}{|c|}{$-0.859^{* *}$} & $\begin{array}{l}-0.880^{* *} \\
(.38)\end{array}$ \\
\hline Sub-Saharan Africa & \multicolumn{2}{|c|}{$\begin{array}{l}-10.591^{* *} \\
(4.36)\end{array}$} & $\begin{array}{l}-10.577^{* *} \\
(4.35)\end{array}$ \\
\hline GDP per capita (logged) & \multicolumn{2}{|c|}{$\begin{array}{l}0.017 \\
(1.06)\end{array}$} & $\begin{array}{l}0.036 \\
(1.07)\end{array}$ \\
\hline Population (logged) & \multicolumn{2}{|c|}{$\begin{array}{l}-1.276 \\
(2.44)\end{array}$} & $\begin{array}{l}-1.128 \\
(2.54)\end{array}$ \\
\hline Main lines (prior) & & & $\begin{array}{l}0.004 \\
(.02)\end{array}$ \\
\hline Obs. & 55 & & 55 \\
\hline
\end{tabular}

Panel A: Performance gains in privatized sectors: Heckman selection model. The dependent variable is the change in the average growth of main lines per employee from 1987-1989 to 2000-2002. Variables included in the first stage model: legal origin, property rights, CPI, primary school enrollment, population size, GDP per capita (initial), main lines per capita (initial).

Panel $B$ : Changes in performance in public and privatized sectors: two-step treatment effects model. The dependent variable in the change in the average growth of main lines per employee from 1987-1989 to 2000-2002. Determinants of the privatization decision: legal origin, property rights, CPI, primary school enrollment, population size, GNP per capita (initial), main lines per capita (initial).

Sample and variable definitions are presented in Appendix A. Robust standard errors are in the parentheses.

*** Statistical significance at $1 \%$ level.

** Statistical significance at $5 \%$ level.

Statistical significance at $10 \%$ level.

tributes to stronger operating efficiency improvements in privatized telecom sectors. Weak property rights protection erodes performance growth.

Other coefficients appear intuitive. Establishment of an independent regulator plays a favorable role in post-privatization performance improvements, and this effect is not overridden by legal or political institutions. An independent regulatory agency may help resolve some of the intra-firm incentive conflicts under private ownership, and an independent regulator may be less likely to engage in expropriation under the guise of oversight. Potential for conflict due to high ethno-linguistic fractionalization has a neg- ative effect. To meaningfully interpret conflict effects, we need to control for regional differences, such as the Sub-Saharan Africa countries characterized by political conflict and weak growth. Indeed, African countries experience worse performance, but the other variables of interest remain significant. All else equal, richer countries see fewer improvements post-privatization, possibly, since they are closer to the optimal level of operating performance whereas poorer countries start out at a lower level and improve at a faster rate as they bridge the gap.

Next we consider the overall effect of privatization alongside institutional quality effects. Are (recently) privatized telecom sectors posting stronger performance improvements than sectors remaining in government ownership? The results are shown in Panel B of Table 7. Privatized sectors perform significantly worse, consistent with our earlier finding for the main sample. Institutional quality results are mixed. ${ }^{11}$ While regulatory reforms matter in the aftermath of ownership changes, they do not lead to performance improvements in the sample of privatized and public sectors.

Robustness checks are shown in Appendix D. In the tests of post-privatization performance in Panel $C$, we add an indicator for full versus partial privatization, which does not enter significantly. Following Li and Xu (2002), who find significant effects of competition, we include competition proxies. More competitive market conditions spur improvements in operating efficiency. (This is in contrast to the tests of profitability, where increases in concentration lead to improved performance.) Property rights effects remain significant. FDI flows are positively related to efficiency, although we exercise caution in interpretation since the effect may not be causal in nature. (Again, this is in a sense in contrast to the broader study, where cross-border privatizations performed more poorly.) Panel D performs robustness checks on the full sample of privatized and government-owned telecom sectors. Inclusion of partial privatizations in the sample may underestimate the positive effects of privatization to performance. We do not find a significant effect of full privatizations. Countries with earlier privatizations might have had more years to realize the full benefits of private ownership. Alternatively, global learning and technological advances would explain better performance of privatizations later in the decade. The early reform effect is not significant.

\subsubsection{Property rights, acquirer-target matching, and privatization deal characteristics}

We now turn to the analysis of privatization transaction attributes in the context of the privatizing country's property rights environment. Table 8 reports estimates of regressions of various characteristics of privatization deals on the property rights index in the privatizing country.

First, we observe the presence of matching of the property rights in the countries of the privatization target and the buyer. Property rights in the buyer's country, regardless of the organizational form of the buyer, appear to be strongly correlated with property rights in the privatizing country. To check whether the observed relationship is driven by domestic privatization deals, we restrict the sample to cross-border privatizations only: the coefficient remains significant, albeit lower in magnitude. Unlike our previous tests, this subset of analyses does not claim a causal effect, and theoretically, two-sided matching is the most plausible explanation for the correlation because either party can walk away from the deal negotiation, rationally pricing in the costs of a potential mismatch in property rights. On the one side, privatizing gov-

\footnotetext{
11 Property rights protection is plausibly more important for privatized telecoms than for the full sample, which also contains state-controlled sectors. Where government expropriation of private owners is naturally less material.
} 
Table 8

Property rights and characteristics of privatization deals.

\begin{tabular}{|c|c|c|c|c|c|c|c|c|}
\hline & \multicolumn{2}{|c|}{ Acquirer property rights } & \multirow[t]{2}{*}{ Crossborder } & \multirow[t]{2}{*}{ Acquirer is privately held } & \multirow[t]{2}{*}{ Acquirer includes labor } & \multirow[t]{2}{*}{ Diversifying } & \multirow[t]{2}{*}{ Percent acq } & \multirow[t]{2}{*}{ Percent own } \\
\hline & All & Crossborder only & & & & & & \\
\hline $\begin{array}{l}\text { Model (1) } \\
\text { Property rights }\end{array}$ & $\begin{array}{l}0.604^{* * *} \\
(.02)\end{array}$ & $\begin{array}{l}0.161^{* * *} \\
(.02)\end{array}$ & $\begin{array}{l}-0.006^{* * *} \\
(.0007)\end{array}$ & $\begin{array}{l}-0.006^{* * *} \\
(.0007)\end{array}$ & $\begin{array}{l}-0.001^{* * *} \\
(.0004)\end{array}$ & $\begin{array}{l}-0.004^{* * *} \\
(.0006)\end{array}$ & $\begin{array}{l}0.813^{* * *} \\
(.05)\end{array}$ & $\begin{array}{l}0.821^{* * * *} \\
(.05)\end{array}$ \\
\hline $\begin{array}{l}\text { Obs. } \\
R^{2}\end{array}$ & $\begin{array}{l}6588 \\
0.46\end{array}$ & $\begin{array}{l}2434 \\
0.10\end{array}$ & $\begin{array}{l}6588 \\
0.05\end{array}$ & $\begin{array}{l}6588 \\
0.06\end{array}$ & $\begin{array}{l}6588 \\
0.03\end{array}$ & $\begin{array}{l}6588 \\
0.07\end{array}$ & $\begin{array}{l}3863 \\
0.14\end{array}$ & $\begin{array}{l}3887 \\
0.14\end{array}$ \\
\hline $\begin{array}{l}\text { Model (2) } \\
\text { Property rights quality }\end{array}$ & $\begin{array}{l}0.685^{* * *} \\
(.01)\end{array}$ & $\begin{array}{l}0.262^{* * *} \\
(.02)\end{array}$ & $\begin{array}{l}-0.044^{* * *} \\
(.01)\end{array}$ & $\begin{array}{l}-0.049^{* * *} \\
(.01)\end{array}$ & $\begin{array}{l}-0.0005 \\
(.004)\end{array}$ & $\begin{array}{l}-0.041^{* * *} \\
(.01)\end{array}$ & $\begin{array}{l}10.273^{* * *} \\
(.60)\end{array}$ & $\begin{array}{l}10.182^{* * *} \\
(.59)\end{array}$ \\
\hline $\begin{array}{l}\text { Obs. } \\
R^{2}\end{array}$ & $\begin{array}{l}6964 \\
0.52\end{array}$ & $\begin{array}{l}2697 \\
0.16\end{array}$ & $\begin{array}{l}6964 \\
0.05\end{array}$ & $\begin{array}{l}6964 \\
0.05\end{array}$ & $\begin{array}{l}6964 \\
0.03\end{array}$ & $\begin{array}{l}6964 \\
0.07\end{array}$ & $\begin{array}{l}4059 \\
0.15\end{array}$ & $\begin{array}{l}4083 \\
0.15\end{array}$ \\
\hline $\begin{array}{l}\text { Model (3) } \\
\text { Control of corruption }\end{array}$ & $\begin{array}{l}0.691^{* * *} \\
(.01)\end{array}$ & $\begin{array}{l}0.247^{* * *} \\
(.02)\end{array}$ & $\begin{array}{l}-0.044^{* * *} \\
(.01)\end{array}$ & $\begin{array}{l}-0.037^{* * * *} \\
(.01)\end{array}$ & $\begin{array}{l}-0.004 \\
(.003)\end{array}$ & $\begin{array}{l}-0.034^{* * *} \\
(.005)\end{array}$ & $\begin{array}{l}8.686^{* * *} \\
(.42)\end{array}$ & $\begin{array}{l}8.602^{* * * *} \\
(.41)\end{array}$ \\
\hline $\begin{array}{l}\text { Obs. } \\
R^{2}\end{array}$ & $\begin{array}{l}6954 \\
0.51\end{array}$ & $\begin{array}{l}2693 \\
0.14\end{array}$ & $\begin{array}{l}6954 \\
0.05\end{array}$ & $\begin{array}{l}6954 \\
0.05\end{array}$ & $\begin{array}{l}6954 \\
0.03\end{array}$ & $\begin{array}{l}6954 \\
0.07\end{array}$ & $\begin{array}{l}4055 \\
0.17\end{array}$ & $\begin{array}{l}4079 \\
0.17\end{array}$ \\
\hline $\begin{array}{l}\text { Model (4) } \\
\text { Rule of law }\end{array}$ & $\begin{array}{l}0.689^{* * *} \\
(.01)\end{array}$ & $\begin{array}{l}0.284^{* * *} \\
(.02)\end{array}$ & $\begin{array}{l}-0.045^{* * *} \\
(.01)\end{array}$ & $\begin{array}{l}-0.046^{* * * *} \\
(.01)\end{array}$ & $\begin{array}{l}0.001 \\
(.003)\end{array}$ & $\begin{array}{l}-0.030^{* * *} \\
(.01)\end{array}$ & $\begin{array}{l}8.882^{* * *} \\
(.55)\end{array}$ & $\begin{array}{l}8.782^{* * *} \\
(.53)\end{array}$ \\
\hline $\begin{array}{l}\text { Obs. } \\
R^{2}\end{array}$ & $\begin{array}{l}6959 \\
0.52\end{array}$ & $\begin{array}{l}2695 \\
0.18\end{array}$ & $\begin{array}{l}6959 \\
0.05\end{array}$ & $\begin{array}{l}6959 \\
0.05\end{array}$ & $\begin{array}{l}6959 \\
0.03\end{array}$ & $\begin{array}{l}6959 \\
0.07\end{array}$ & $\begin{array}{l}4056 \\
0.15\end{array}$ & $\begin{array}{l}4080 \\
0.14\end{array}$ \\
\hline $\begin{array}{l}\text { Model (5) } \\
\text { Political stability }\end{array}$ & $\begin{array}{l}0.731^{* * *} \\
(.01)\end{array}$ & $\begin{array}{l}0.260^{* * * *} \\
(.02)\end{array}$ & $\begin{array}{l}0.004 \\
(.01)\end{array}$ & $\begin{array}{l}-0.055^{* * *} \\
(.01)\end{array}$ & $\begin{array}{l}0.005 \\
(.004)\end{array}$ & $\begin{array}{l}-0.043^{* * *} \\
(.01)\end{array}$ & $\begin{array}{l}6.201^{* * *} \\
(.67)\end{array}$ & $\begin{array}{l}6.355^{* * *} \\
(.65)\end{array}$ \\
\hline $\begin{array}{l}\text { Obs. } \\
R^{2}\end{array}$ & $\begin{array}{l}6962 \\
0.60\end{array}$ & $\begin{array}{l}2695 \\
0.16\end{array}$ & $\begin{array}{l}6962 \\
0.04\end{array}$ & $\begin{array}{l}6962 \\
0.05\end{array}$ & $\begin{array}{l}6962 \\
0.03\end{array}$ & $\begin{array}{l}6962 \\
0.07\end{array}$ & $\begin{array}{l}4057 \\
0.11\end{array}$ & $\begin{array}{l}4081 \\
0.11\end{array}$ \\
\hline $\begin{array}{l}\text { Model (6) } \\
\text { Property rights }\end{array}$ & $\begin{array}{l}0.578^{* * * *} \\
(.02)\end{array}$ & $\begin{array}{l}0.151^{* * *} \\
(.03)\end{array}$ & $\begin{array}{l}-0.005^{* * *} \\
(.001)\end{array}$ & $\begin{array}{l}-0.007^{* * *} \\
(.001)\end{array}$ & $\begin{array}{l}-0.002^{* * *} \\
(.001)\end{array}$ & $\begin{array}{l}-0.003^{* * *} \\
(.001)\end{array}$ & $\begin{array}{l}0.078 \\
(.10)\end{array}$ & $\begin{array}{l}0.139 \\
(.09)\end{array}$ \\
\hline $\begin{array}{l}\text { Obs. } \\
R^{2}\end{array}$ & $\begin{array}{l}6439 \\
0.47\end{array}$ & $\begin{array}{l}2377 \\
0.11\end{array}$ & $\begin{array}{l}6439 \\
0.05\end{array}$ & $\begin{array}{l}6439 \\
0.06\end{array}$ & $\begin{array}{l}6439 \\
0.03\end{array}$ & $\begin{array}{l}6439 \\
0.07\end{array}$ & $\begin{array}{l}3786 \\
0.17\end{array}$ & $\begin{array}{l}3810 \\
0.17\end{array}$ \\
\hline
\end{tabular}

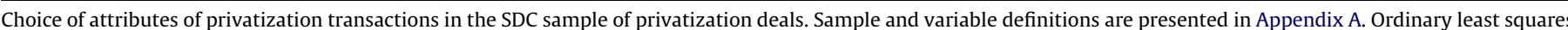

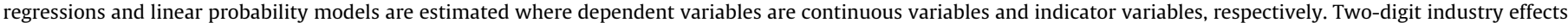

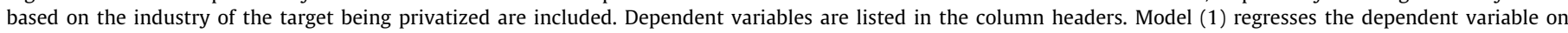

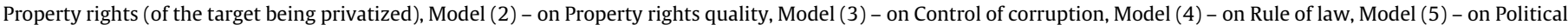
stability, and Model (6) - on Property rights and GDP per capita (both of the target being privatized). Robust standard errors are in the parentheses.

* Statistical significance at $10 \%$ level.

** Statistical significance at $5 \%$ level.

*** Statistical significance at $1 \%$ level.

ernments in strong property rights environments benefit when buyers are protected from expropriation because such buyers have the right incentives to improve the efficiency of former SOEs under private ownership and offer a price for the privatization target that is reflective of the expected value gains. In turn, privatizing governments in weak property rights countries are less likely to value efficiency improvements and strong acquirer property rights and will focus on preserving the potential for government expropriation and rent extraction after the change in ownership. On the other side, from the buyer's standpoint, familiarity with a particular property rights environment offers a comparative advantage. Buyers from strong property rights countries are more averse to partaking in privatizations involving weak property rights targets because such buyers are less adept at managing government expropriation and corruption risks.

Better property rights in the privatizing country are also associated with greater odds of a domestic buyer, which is intuitive, considering the evidence of matching of property rights environments. Additionally, strong property rights are associated with lower odds of a diversifying acquisition (to the extent that diversifying deals are more likely to erode value, the finding supports the intuition that strong property rights increase the probability of value creation conditional on a privatization occurring). Further, strong property rights are associated with lower odds of an employee buyout (employee involvement on the buy side may result in more stakeholder rather than investor value focus, potentially delaying some efficiency improvements associated with privatization), larger stakes, and higher odds of a publicly listed buyer. One interpretation is that when property rights protections are strong, publicly listed acquirers are able to avoid government expropriation and maintain a long-term focus on mitigating intra-firm incentive problems.

\section{Discussion and conclusions}

In this paper we have examined the implications of property and contracting rights for post-privatization performance in the context of the tradeoffs of privatization reforms.

We presented evidence that the quality of property rights protection against government expropriation and rent seeking served as a significant determinant of post-privatization performance. We also found positive effects of strong contracting rights and an effective judicial system on post-privatization performance. Good overall quality of political institutions had weak effects on postprivatization performance.

Our empirical analysis pointed out the importance of accounting for the non-random nature of privatizations, in particular, the 
tendency to include better past performers in the privatization group, which has the effect of confounding privatization effects on performance and biasing estimates upward. Controlling for this bias lends a new dimension to the conventional wisdom about performance outcomes of privatization. Privatizations of state-owned enterprises are followed by a transition period, during which incentive conflicts and restructuring costs (including those associated with subsidy reductions) temporarily counter efficiency improvements under private ownership. Empirically, this translates into short-term relative underperformance of privatizations. Such short-term tradeoffs are most relevant in cases of significant reliance on government subsidies prior to the reform. The tradeoffs disappear in the long run (after 10 years following reform completion). This does not imply that private ownership is inefficient, but rather that the long-term benefits of private ownership are not realized immediately and that the privatization process involves a costly adjustment for the target firm. Moreover, property rights are a significant determinant of post-privatization performance. Further, the property rights regime in the privatizing country has implications for the nature and attributes of privatization deals.

The general pattern of the findings, particularly, the role of property rights for post-privatization performance, is also confirmed by the industry study of efficiency changes in the telecom sector, prominent for its large scale, fiscally motivated privatization reforms.

The evidence presented above sheds light on the effects of property rights and privatization-related ownership changes for performance. Below we discuss several policy implications. Based on our analysis, it becomes apparent that "one size does not fit all" in the design of ownership reforms. Strong property rights and contracting rights are instrumental to the success of public-to-private ownership transitions. Further, while privatized enterprises generally perform well in absolute terms, it is in part due to selection. While incentive benefits are realized in the long run, they are not immediate, and direct and indirect costs of privatization may hinder relative performance in the short run, especially when dependence on government subsidies was considerable in the past or expropriation risks are high.

The fact that our "property rights" measure is correlated with improved performance of public sector enterprises means that it is capturing more than just the risk of expropriation, and is a broader indicator of "institutional quality." Indeed, a basic insight is that institutional quality matters more than ownership.

Our paper sheds light on a long standing debate in the reform literature: should privatization precede or follow the creation of good institutional structures. The advocates of rapid transition suggested that privatization would directly lead to increased performance and eventually lead to the other necessary legal and institutional reforms. Advocates of gradualism countered that without good institutional structure, privatization would not lead to improved performance. ${ }^{12}$ The experience of Russia, as well as the broader study of Godoy and Stiglitz (2007), supports the gradualist hypothesis: GDP declined with privatization, faster privatization did not lead to improved performance, and in many of the countries, good institutions have yet to be created. This study provides further micro-economic support: institutional design is critical for the success of privatization, and even with reasonably good institutional design, it takes a very long time - beyond the period of this study (which extends up to 15 years after privatization) - for privati-

\footnotetext{
12 Hoff and Stiglitz (2004a, b, 2008) and Stiglitz (2000a) provide a theoretical analysis of the difficulties not only associated with privatization, especially in the presence of weak legal protections and poor corporate governance, but also with the change in the legal regime.
}

zation gains to be evident for those firms that were previously the recipients of significant subsidies.

\section{Acknowledgments}

We are grateful to Meghana Ayyagari, Rayna Brown, Tatiana Didier, Nicholas Economides, William Greene, Bruce Greenwald, Kose John, Barbara Katz, Raphael Lam, Jianping Mei, Bill Schwert, Cliff Smith, Jan Svejnar, David Yermack, and Bernard Yeung for discussions and valuable suggestions on earlier drafts. We also thank seminar and conference participants at New York University, North American Productivity Workshop IV, INFINITI Conference on International Finance, Financial Management Association meeting, Western Economic Association, and Washington Area Finance Association meeting for comments. All remaining errors and omissions are our own. Joseph E. Stiglitz is indebted to the The Institute for New Economic Thinking (INET) for financial support. Anzhela Knyazeva and Diana Knyazeva acknowledge financial support of Leonard N. Stern School of Business and William E. Simon Graduate School of Business Administration.

\section{Appendix A. Sample and variable definitions and summary statistics}

Main sample: The main sample for the study of privatization and property rights on sector performance across all industries covers European countries and is drawn from the Privatization Barometer (PB) for 1990-2009. Due to lacking firm level identifiers and ensuing firm level matching challenges, PB data is aggregated to the two-digit SIC industry level by privatization year. It is combined with Compustat Global (CG) data that is similarly aggregated to the two-digit SIC level for the countries for which both databases have coverage (Western and Eastern Europe economies) to construct the 'all (privatized and public) sectors' sample. The 'privatized' sample includes industries in Europe that have one or more privatization deals recorded in $\mathrm{PB}$ in a given year. Foreign currency amounts are converted into USD using Compustat Global currency exchange rate data. We require information on performance and the main controls. Additional sample selection criteria are imposed where indicated. Regressions accounting for endogeneity of privatization also require information on sector/country privatization determinant variables. Property rights data availability affects sample size. Where indicated, we use information on privatizations reported in SDC Platinum, as a robustness test and to examine the effects of property rights in the acquirer (buyer) country on performance of the privatized sector. We focus on cases of target firms identified as having "government" ownership status and acquirers that are non-government. Data is similarly aggregated to two-digit SIC industry level using the industry of the target, for each year. Macroeconomic data is obtained from World Bank's World Development Indicators (WDI).

ce:italic>Telecom sector study: The telecom sector privatization sample includes privatizations conducted between 1990 and 2000 and the list of countries whose telecom sectors have remained public, based on Wallsten (2002). Telecom sector data is obtained from the International Telecommunications Union (ITU) and WDI.

Deal study: The sample of acquisition transactions obtained from SDC data. Privatizations are identified as transactions involving government-owned targets and non-government-owned buyers. Property rights data for the target being privatized and the acquirer must be available. Models using Property rights (based on ICRG data) use the 1985-2010 sample. Models using Property rights quality (based on World Governance Indicators (WGI) and Kaufmann, Kraay, and Mastruzzi (KKM) data) use the 1990-2010 sample. 


\section{Panel A: Variable definitions \\ Sector-level study \\ (main sample)}

Privatization

Equal to 1 if one or more privatization deals are recorded in the sector.

Source: PB or SDC, as specified

Profitability

One-year lead of the percent of operating income before depreciation in total assets. Source: CG

Protection of private property rights from expropriation Property rights Investment Country Risk Guide (ICRG) country rating; ranges from 0 (weak rights) to 100 (strong rights). Source: WDI. Values after 2003 filled in with 2003 values due to data constraints

Control of corruption Score ranging between -2.5 (weak rights) and 2.5 (strong rights) that reflects the level of control over corruption in the country. Source: WGI, KKM

Rule of law Score ranging between -2.5 (weak rights) and 2.5 (strong rights) that reflects the quality of the rule of law in the country. Source: WGI, KKM

Rule of law and Average of Rule of law and Control of corruption control corruption (see above)

Contractual rights and legal system

Legal formalism The index of formality in legal procedures for collecting on a bounced check. Lower values indicate greater ease of contract enforcement and a lesser degree of legal formalism. Source: Djankov et al. (2003)

Difficulty of enforcing The average number of procedures contracts (procedures) required to enforce a contract. Lower values indicate greater ease of contract enforcement. Source: World Bank Doing Business Indicators (DBI)

Difficulty of enforcing The average number of days required contracts (days)

Effectiveness of the judicial system

Courts

Legal system and to enforce a contract. Lower values indicate greater ease of contract enforcement. Source: DBI

Higher values indicate a more effective judicial system. Source: La Porta et al. (1998)

Average of the score on the dimensions of Judicial Independence and Impartial Courts. Higher values indicate a more independent court system. Source: Economic Freedom of the World (EFW)

Legal system Average of the score on the dimensions of Judicial Independence, Impartial Courts, and Integrity of the Legal System. Higher values indicate a better legal system. Source: EFW Average of the score on the contract enforcement dimensions of Judicial Independence, Impartial Courts, Integrity of the Legal System, and Legal Enforcement

Sample and variable definitions and summary statistics (continued)

Panel A: Variable definitions

Sector-level study

(main sample)

of Contracts. Higher values indicate a better legal system and more effective contract enforcement. Source: EFW

Political environment

Constraint on the executive

Limited government

Government effectiveness

Regulatory quality

Regulations

Political stability

Voice and accountability

Aggregate measure Property rights quality

Controls

Size

Growth opportunities

Industry concentration

Economic growth

Income per capita

Past labor/assets
An index ranging from 1 to 7 that captures the extent of subordination of the executive. Higher values indicate greater limits on executive power. Source: Polity IV Score on the dimension of Size of Government: Expenditures, Taxes, and Enterprises. Higher values indicate a smaller, more limited government. Source: EFW Score ranging between -2.5 (weak rights) and 2.5 (strong rights) that reflects the effectiveness of the government. Source: WGI, KKM Score ranging between -2.5 (weak rights) and 2.5 (strong rights) that reflects the regulatory quality in the country. Source: WGI, KKM

Score on the dimension of Regulation of Credit, Labor, and Business. Higher values indicate a better regulatory environment. Source: EFW

Score ranging between -2.5 (weak rights) and 2.5 (strong rights) that reflects the extent of political stability in the country. Source: WGI, KKM Score ranging between -2.5 (weak rights) and 2.5 (strong rights) that reflects the extent of democratic voice and accountability in the country. Source: WGI, KKM

Score ranging between -2.5 (weak rights) and 2.5 (strong rights) that is constructed as the average of control of corruption, rule of law, political stability, government effectiveness, regulatory quality, and voice and accountability scores. Source: WGI, KKM

Average log of net sales in USD in the sector. Source: CG

Average annual growth in net sales in the sector. Source: CG

Herfindahl index based on net sales in USD. Source: CG

Annual growth in GDP per capita in constant 2000 USD. Source: WDI Log of GDP per capita in constant 2000 USD. Source: WDI One-year lag of the sector average 
Sample and variable definitions and summary statistics (continued)

Panel A: Variable definitions
Sector-level study
(main sample)

\begin{tabular}{|c|c|}
\hline & $\begin{array}{l}\text { employees per thousand of dollars in } \\
\text { net sales. Source: CG }\end{array}$ \\
\hline Past sector size (logged) & $\begin{array}{l}\text { One-year lag of the log of total assets } \\
\text { of firms in the sector in USD. Source: } \\
\text { CG }\end{array}$ \\
\hline $\begin{array}{l}\text { Past population } \\
\text { (logged) }\end{array}$ & $\begin{array}{l}\text { One-year lag of the log of total } \\
\text { population in the country. Source: } \\
\text { WDI }\end{array}$ \\
\hline $\begin{array}{l}\text { Past government } \\
\text { spending }\end{array}$ & $\begin{array}{l}\text { One-year lag of percent of } \\
\text { government expenditure in GDP. } \\
\text { Source: WDI }\end{array}$ \\
\hline Initial income per capita & $\begin{array}{l}\text { Log of GDP per capita in USD for } \\
\text { 1989. Source: WDI }\end{array}$ \\
\hline Past profitability & $\begin{array}{l}\text { One year lag of profitability (see } \\
\text { above) }\end{array}$ \\
\hline $\begin{array}{l}\text { Initial state sector } \\
\text { employment }\end{array}$ & $\begin{array}{l}\text { Average of the ratio of public sector } \\
\text { employment in general government } \\
\text { to total employment. Source: La Porta } \\
\text { et al. (2002) }\end{array}$ \\
\hline French legal origin & $\begin{array}{l}\text { Equal to } 1 \text { if the country has French } \\
\text { legal origin; } 0 \text { otherwise. Source: La } \\
\text { Porta et al. (1999) }\end{array}$ \\
\hline Privatization value & $\begin{array}{l}\text { Ratio of the total value of } \\
\text { privatization deals to total assets of } \\
\text { firms in the sector. Source: PB or SDC, } \\
\text { as specified, and CG }\end{array}$ \\
\hline Privatization stake & $\begin{array}{l}\text { Average percentage stake being } \\
\text { privatized in the sector. Source: PB }\end{array}$ \\
\hline Privatization deals & $\begin{array}{l}\text { Log of one plus the number of } \\
\text { privatization deals in the sector. } \\
\text { Source: PB or SDC, as specified }\end{array}$ \\
\hline $\begin{array}{l}\text { Deals that are public } \\
\text { offers }\end{array}$ & $\begin{array}{l}\text { Proportion of privatizations } \\
\text { conducted as public offerings Source: } \\
\text { PB }\end{array}$ \\
\hline $\begin{array}{l}\text { Acquirer property rights } \\
\text { quality }\end{array}$ & $\begin{array}{l}\text { Average Property rights quality in the } \\
\text { countries of Acquirers involved in } \\
\text { privatization deals. Source: SDC } \\
\text { Acquirer control of corruption, } \\
\text { Acquirer rule of law, and Acquirer } \\
\text { political stability are defined } \\
\text { similarly }\end{array}$ \\
\hline
\end{tabular}

\section{Telecom study}

Change in main lines Change in levels and growth rates of per employee

French (English) legal origin

Property rights

Regulator main lines (main telephone lines in operation, in thousands) per total full time telecommunications staff Source: ITU, WDI

Equal to 1 if the country has French (English) legal origin; 0 otherwise. Source: La Porta et al. (1999) Investment Country Risk Guide country rating; ranges from 0 (low risk) to 100 (high risk). Source: WDI Dummy equal to 1 if an autonomous
Sample and variable definitions and summary statistics (continued)

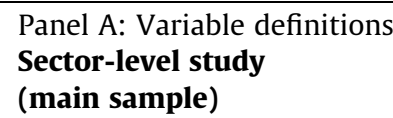

Regulator before privatization

Dummy equal to 1 if an autonomous

Domestic bank credit privatization; 0 otherwise. Source: Guillen et al. (2004), Wallsten (2002)

Initial budget balance/ Average percentage of budget balance GDP

Net FDI

Full privatization Net foreign direct investment to GDP. Source: WDI

Dummy equal to 1 if the country implemented a full privatization reform; 0 otherwise. Source: Guillen et al. (2004)

Early privatization Dummy variable equal to 1 if the privatization was implemented in 1995 or earlier; 0 otherwise

Local competition

Long distance competition

Initial main line penetration

Initial GNP per capita Log of GNP per capita for 1970-1995 Average of the competition index, for local telephony. Source: $\mathrm{Li}$ and $\mathrm{Xu}$ (2002)

Average of the competition index, for long distance telephony. Source: Li and $\mathrm{Xu}$ (2002)

Average of main lines per 100 inhabitants for years [1982, 1983, 1984] (for 1975, 1976, 1977 for Chile). Source: ITU/WDI in USD (log). Source: La Porta et al. (1999)

Initial GDP per capita Average GDP per capita (log) in 19821984. Source: WDI

Initial CPI inflation

Average percentage change in consumer prices in 1982-1984. Source: WDI

Initial population size Average population (log) in 19821984. Source: WDI

Sub-Saharan Africa Binary variable for Sub-Saharan Africa country classification. Source: WB

Ethno-linguistic fractionalization Ethno-linguistic fractionalization, from 0 to 100. Source: La Porta et al. (1999)

Primary enrollment Enrollment in primary schools, total, regulator is present; 0 otherwise. Source: Guillen et al. (2004), Wallsten (2002) $\%$ of labor force in 1990. Source: WDI

Life expectancy Average life expectancy at birth, total, in 1990. Source: WDI

\section{Privatization deal attributes study}

Cross-border

Equal to 1 if the acquirer is in a different country than the target being privatized. Source: SDC

Acquirer is privately Equal to 1 if the acquirer is privately held held (not listed publicly on an exchange)

Acquirer includes labor Equal to 1 if the acquirer includes employees, management, or employee stock ownership plan. 
Sample and variable definitions and summary statistics (continued)

\section{Panel A: Variable definitions \\ Sector-level study \\ (main sample)}

\begin{tabular}{ll}
\hline \multirow{2}{*}{ Diversifying } & Source: SDC \\
& Equal to 1 if the acquirer and target \\
& are from different SIC4 industries. \\
& Source: SDC \\
Percent acq & Percentage stake the buyer is seeking \\
& to acquire in the privatization \\
& transaction. Source: SDC \\
Percent own & Percentage stake the buyer is seeking \\
& to own after the privatization \\
& transaction. Source: SDC \\
\hline
\end{tabular}

Panel B: Summary statistics of the main variables Obs. Mean Median Std.

Dev.

\begin{tabular}{|c|c|c|c|c|}
\hline \multicolumn{5}{|l|}{ Main sample } \\
\hline \multicolumn{5}{|l|}{ Privatized sectors } \\
\hline Profitability & 632 & 10.32 & 10.10 & 7.25 \\
\hline \multicolumn{5}{|c|}{ Protection of private property rights from expropriation } \\
\hline Property rights & 632 & 81.51 & 81.80 & 3.61 \\
\hline Control of corruption & 627 & 1.59 & 1.73 & 0.62 \\
\hline Rule of law & 627 & 1.44 & 1.58 & 0.37 \\
\hline $\begin{array}{l}\text { Rule of law and corruption } \\
\text { control }\end{array}$ & 627 & 1.51 & 1.69 & 0.48 \\
\hline \multicolumn{5}{|c|}{ Contractual rights and legal system } \\
\hline Legal formalism & 628 & 3.50 & 3.51 & 0.71 \\
\hline $\begin{array}{l}\text { Difficulty of enforcing } \\
\text { contracts (procedures) }\end{array}$ & 632 & 32.78 & 30.00 & 4.88 \\
\hline $\begin{array}{l}\text { Difficulty of enforcing } \\
\text { contracts (days) }\end{array}$ & 632 & 491 & 404 & 187 \\
\hline $\begin{array}{l}\text { Effectiveness of the judicial } \\
\text { system }\end{array}$ & 612 & 8.40 & 9.00 & 1.52 \\
\hline Courts & 550 & 7.41 & 7.75 & 1.64 \\
\hline Legal system & 550 & 7.91 & 8.28 & 1.42 \\
\hline $\begin{array}{l}\text { Legal system and contract } \\
\text { enforcement }\end{array}$ & 550 & 7.77 & 7.82 & 1.43 \\
\hline \multicolumn{5}{|l|}{ Political environment } \\
\hline $\begin{array}{l}\text { Constraint on the } \\
\text { executive }\end{array}$ & 632 & 6.86 & 7.00 & 0.34 \\
\hline Limited government & 627 & 1.24 & 1.28 & 0.21 \\
\hline Government effectiveness & 632 & 4.49 & 4.60 & 1.13 \\
\hline Regulatory quality & 627 & 1.60 & 1.76 & 0.45 \\
\hline Regulations & 627 & 1.20 & 1.15 & 0.32 \\
\hline Political stability & 632 & 6.59 & 6.40 & 0.91 \\
\hline $\begin{array}{l}\text { Voice and accountability } \\
\text { Controls }\end{array}$ & 627 & 0.90 & 0.88 & 0.30 \\
\hline Size & 632 & 6.99 & 7.18 & 1.32 \\
\hline Growth opportunities & 632 & 0.17 & 0.11 & 0.42 \\
\hline Economic growth & 632 & 2.04 & 2.08 & 1.89 \\
\hline GDP per capita & 632 & 9.84 & 9.92 & 0.36 \\
\hline Industry concentration & 785 & 0.55 & 0.50 & 0.31 \\
\hline Privatization deals & 695 & 1.75 & 1.61 & 0.73 \\
\hline Privatization value & 695 & 1.45 & 0.07 & 7.43 \\
\hline Privatization stake & 695 & 57.84 & 52.17 & 35.92 \\
\hline Deals that are public offers & 695 & 0.34 & 0.00 & 0.46 \\
\hline
\end{tabular}

Sample and variable definitions and summary statistics (continued)

Panel B: Summary statistics of the main variables

Obs. Mean Median Std.

Dev.

\begin{tabular}{lllll}
\hline All sectors (main sample) & & & & \\
Profitability & 10,746 & 9.46 & 9.86 & 8.62 \\
Privatization & 10,746 & 0.07 & 0.00 & 0.26 \\
Property rights quality & 10,718 & 1.33 & 1.42 & 0.36 \\
Control of corruption & 10,718 & 1.54 & 1.55 & 0.65 \\
Rule of law & 10,718 & 1.41 & 1.57 & 0.41 \\
Political stability & 10,718 & 0.91 & 0.91 & 0.32 \\
Property rights & 10,746 & 81.78 & 82.00 & 3.90 \\
Size & 10,746 & 6.07 & 6.16 & 1.74 \\
Growth opportunities & 10,746 & 0.13 & 0.08 & 0.44 \\
GDP per capita & 10,746 & 9.81 & 9.96 & 0.49 \\
Industry concentration & 10,746 & 0.64 & 0.60 & 0.31
\end{tabular}

\section{Privatized sectors (SDC sample)}

Acquirer property rights quality

Acquirer control of corruption

Acquirer rule of law

Acquirer political stability

Telecom sample

Change in growth of main lines per employee

French legal origin

English legal origin

Property rights

Regulator

Regulator (prior)

Budget balance

Domestic bank credit

Net FDI

Competition (local)

Competition (long distance)

Life expectancy

Primary enrollment

Ethno-linguistic fractionalization

Sub-Saharan Africa

Main lines per 100 inhabitants

GNP per capita

Population size

Early privatization

Full privatization

\begin{tabular}{|c|c|c|c|}
\hline 704 & 0.88 & 1.22 & 0.78 \\
\hline 704 & 1.07 & 1.35 & 1.00 \\
\hline 704 & 0.97 & 1.33 & 0.83 \\
\hline 704 & 0.52 & 0.83 & 0.73 \\
\hline 74 & 2.49 & 1.46 & 13.89 \\
\hline 105 & 0.48 & 0.00 & 0.50 \\
\hline 105 & 0.26 & 0.00 & 0.44 \\
\hline 76 & 58.71 & 54.42 & 16.14 \\
\hline 105 & 0.82 & 1.00 & 0.39 \\
\hline 105 & 0.36 & 0.00 & 0.48 \\
\hline 78 & -3.14 & -2.61 & 4.69 \\
\hline 84 & 56.54 & 45.91 & 44.62 \\
\hline 84 & 1.12 & 0.49 & 2.07 \\
\hline 89 & 0.85 & 0.00 & 1.18 \\
\hline 92 & 0.74 & 0.00 & 1.18 \\
\hline 103 & 64.05 & 67.60 & 10.49 \\
\hline 99 & 92.01 & 98.37 & 22.51 \\
\hline 90 & 0.37 & 0.33 & 0.30 \\
\hline 105 & 0.29 & 0.00 & 0.45 \\
\hline 103 & 12.56 & 4.80 & 16.55 \\
\hline 103 & 7.27 & 7.15 & 1.39 \\
\hline 101 & 0.28 & 0.70 & 1.00 \\
\hline 66 & 0.47 & 0.00 & 0.50 \\
\hline 105 & 0.11 & 0.00 & 0.31 \\
\hline
\end{tabular}

Privatization deals sample

Property rights quality

Control of corruption

Rule of law

Political stability

Property rights

Acquirer property rights quality

Acquirer control of corruption

Acquirer rule of law

Acquirer political stability

Acquirer property rights

$\begin{array}{llll}6964 & 0.54 & 0.78 & 0.85 \\ 6955 & 0.58 & 0.53 & 1.13 \\ 6960 & 0.59 & 0.85 & 0.94 \\ 6963 & 0.34 & 0.68 & 0.83 \\ 6588 & 74.21 & 75.30 & 9.62 \\ 6964 & 0.81 & 1.16 & 0.82 \\ & & & \\ 6957 & 0.95 & 1.34 & 1.11 \\ & & & \\ 6960 & 0.89 & 1.30 & 0.91 \\ 6963 & 0.49 & 0.83 & 0.79 \\ 6588 & 77.09 & 79.50 & 8.74\end{array}$


Sample and variable definitions and summary statistics

(continued)

\begin{tabular}{lllll}
\hline \multicolumn{4}{l}{ Panel B: Summary statistics of the main variables } \\
& Obs. & Mean & Median & Std. \\
& & & & Dev. \\
\hline Cross-border & 6964 & 0.39 & 0.00 & 0.49 \\
Acquirer is privately held & 6964 & 0.57 & 1.00 & 0.50 \\
Acquirer includes labor & 6964 & 0.08 & 0.00 & 0.27 \\
Diversifying & 6964 & 0.73 & 1.00 & 0.45 \\
Percent acq & 4059 & 72.02 & 84.65 & 31.66 \\
Percent own & 4083 & 73.31 & 85.00 & 30.66 \\
\hline
\end{tabular}

\section{Appendix B. Privatization determinants (main sample)}

Probit of privatization likelihood in the European sample of all industries. Column I reports the main model. Column II-IV add controls for robustness. Exclusion of Initial income and French legal origin determinants from the first stage does not materially affect model results. Robust standard errors are in the parentheses.

\begin{tabular}{|c|c|c|c|c|}
\hline & I & II & III & IV \\
\hline Initial income per capita & $\begin{array}{l}-0.558^{* * *} \\
(0.11)\end{array}$ & $\begin{array}{l}-0.564^{* * *} \\
(0.12)\end{array}$ & $\begin{array}{l}-0.480^{* *} \\
(0.19)\end{array}$ & $\begin{array}{l}-1.688^{* * * *} \\
(0.28)\end{array}$ \\
\hline French legal origin & $\begin{array}{l}-0.097^{*} \\
(0.06)\end{array}$ & $\begin{array}{l}-0.114^{* *} \\
(0.06)\end{array}$ & $\begin{array}{l}-0.041 \\
(0.08)\end{array}$ & $\begin{array}{l}-0.533^{* * *} \\
(0.10)\end{array}$ \\
\hline Past population (logged) & $\begin{array}{l}0.242^{* * *} \\
(0.03)\end{array}$ & $\begin{array}{l}0.244^{* * *} \\
(0.03)\end{array}$ & $\begin{array}{l}0.124^{* * *} \\
(0.04)\end{array}$ & $\begin{array}{l}0.293^{* * *} \\
(0.04)\end{array}$ \\
\hline Past labor/assets & $\begin{array}{l}(1 . E-04) \\
4 . E-03\end{array}$ & $\begin{array}{l}-0.004 \\
4 . E-03\end{array}$ & $\begin{array}{l}0.001 \\
5 . E-03\end{array}$ & $\begin{array}{l}0.006 \\
5 . E-03\end{array}$ \\
\hline Past sector size (logged) & $\begin{array}{l}0.030^{* *} \\
(0.01)\end{array}$ & $\begin{array}{l}0.037^{* * *} \\
(0.01)\end{array}$ & $\begin{array}{l}0.027 \\
(0.02)\end{array}$ & $\begin{array}{l}0.056^{* * *} \\
(0.02)\end{array}$ \\
\hline Past government spending & $\begin{array}{l}0.028^{* *} \\
(0.01)\end{array}$ & $\begin{array}{l}0.031^{* * *} \\
(0.01)\end{array}$ & $\begin{array}{l}0.010 \\
(0.02)\end{array}$ & $\begin{array}{l}0.094^{* * *} \\
(0.02)\end{array}$ \\
\hline Past profitability & & $\begin{array}{l}1.456^{* * *} \\
(0.36)\end{array}$ & & \\
\hline Initial profitability & & & $\begin{array}{l}0.007 \\
(4 . E-03)\end{array}$ & \\
\hline Initial state sector employment & & & & $\begin{array}{l}-3.239^{* *} \\
(1.52)\end{array}$ \\
\hline Obs. & 8795 & 8795 & 3599 & 7378 \\
\hline Pseudo- $R^{2}$ & 0.207 & 0.211 & 0.071 & 0.215 \\
\hline
\end{tabular}

\section{Appendix C. Robustness tests for the main sample}

Sample and variable definitions are presented in Appendix A. The dependent variable is profitability (1-year lead). Privatization indicator equals one if one or more deals was reported in the sector in a given period. Two-digit industry effects are included. Robust standard errors are in the parentheses. Statistical significance at $1 \%, 5 \%$, and $10 \%$ levels is denoted with ${ }^{* * *}$, ${ }^{* *}$, and ${ }^{*}$, respectively.

Panel A: Property rights effects on the performance of privatized industries in the sample of privatizations. The main sample of European privatizations is used in Columns I-III. Column I excludes observations with missing data on privatization determinants in Table C1 for comparability with privatization observations used in the selection model. Column II excludes privatizations in the financial sector (SIC 6000-6999). Column III enhances the specification with additional controls. The SDC sample of privatizations in all countries is used in Column IV.

Panel B: Regressions of privatization and property rights effects on performance in the sample of all (privatized and public) sectors. Columns I-IV use ordinary least squares. Column V uses treatment effects estimation using first-stage determinants in Table C1 to predict privatization. The main sample of European privatizations is used in Columns I-III. Column I excludes observations with missing data on privatization determinants. Column II excludes privatizations in the financial sector (SIC 6000-6999). Columns IV-V use the SDC sample of privatizations in all countries (observations with missing data on privatization determinants are excluded). 


\begin{tabular}{|c|c|c|c|c|c|}
\hline & I & & II & III & IV \\
\hline \multicolumn{6}{|c|}{ Panel A. Property rights effects on the performance of privatized sectors } \\
\hline Property rights quality & \multicolumn{2}{|c|}{$\begin{array}{l}4.539^{* * *} \\
(.95)\end{array}$} & $\begin{array}{l}4.053^{* * *} \\
(.91)\end{array}$ & $\begin{array}{l}2.685^{* * *} \\
(.95)\end{array}$ & $\begin{array}{l}2.414^{* * *} \\
(.82)\end{array}$ \\
\hline Size & \multicolumn{2}{|l|}{$\begin{array}{l}1.211^{* * *} \\
(.35)\end{array}$} & $\begin{array}{l}1.089^{* * *} \\
(.27)\end{array}$ & $\begin{array}{l}1.368^{* * *} \\
(.32)\end{array}$ & $\begin{array}{l}1.688^{* * *} \\
(.28)\end{array}$ \\
\hline Growth opportunities & \multicolumn{2}{|l|}{$\begin{array}{l}0.152 \\
(1.48)\end{array}$} & $\begin{array}{l}-0.046 \\
(1.21)\end{array}$ & $\begin{array}{l}0.245 \\
(1.32)\end{array}$ & $\begin{array}{l}0.445 \\
(.47)\end{array}$ \\
\hline \multicolumn{4}{|l|}{ Privatization deals } & $\begin{array}{l}0.795 \\
(.55)\end{array}$ & \\
\hline \multicolumn{4}{|l|}{ Privatization stake } & $\begin{array}{l}0.018 \\
(.01)\end{array}$ & \\
\hline \multicolumn{4}{|l|}{ Privatization value } & $\begin{array}{l}0.036 \\
(.04)\end{array}$ & \\
\hline \multicolumn{4}{|l|}{ Deals that are public offers } & $\begin{array}{l}1.187 \\
(.73)\end{array}$ & \\
\hline \multicolumn{4}{|l|}{ Industry concentration } & $\begin{array}{l}2.476^{* *} \\
(1.25)\end{array}$ & \\
\hline Income per capita & \multicolumn{2}{|l|}{$\begin{array}{l}-10.843^{* * *} \\
(1.34)\end{array}$} & $\begin{array}{l}-5.191^{* * *} \\
(.80)\end{array}$ & $\begin{array}{l}-5.051^{* * *} \\
(.83)\end{array}$ & $\begin{array}{l}-3.259^{* * * *} \\
(.61)\end{array}$ \\
\hline \multirow[t]{2}{*}{$\begin{array}{l}\text { Obs. } \\
R^{2}\end{array}$} & $\begin{array}{l}607 \\
0.26\end{array}$ & & $\begin{array}{l}767 \\
0.21\end{array}$ & $\begin{array}{l}692 \\
0.24\end{array}$ & $\begin{array}{l}713 \\
0.27\end{array}$ \\
\hline & I & II & III & IV & $\mathrm{V}$ \\
\hline \multicolumn{6}{|c|}{ Panel B. Property rights and privatization effects on performance (all sectors) } \\
\hline Privatization & $\begin{array}{l}0.509 \\
(.32)\end{array}$ & $\begin{array}{l}0.056 \\
(.28)\end{array}$ & $\begin{array}{l}-1.262 \\
(1.11)\end{array}$ & $\begin{array}{l}-0.004 \\
(.41)\end{array}$ & $\begin{array}{l}-13.638^{* * * *} \\
(.58)\end{array}$ \\
\hline Property rights quality & $\begin{array}{l}4.078^{* * *} \\
(.32)\end{array}$ & $\begin{array}{l}3.800^{* * *} \\
(.28)\end{array}$ & $\begin{array}{l}3.099^{* * *} \\
(.30)\end{array}$ & $\begin{array}{l}2.097^{* * *} \\
(.20)\end{array}$ & $\begin{array}{l}1.912^{* * *} \\
(.20)\end{array}$ \\
\hline Size & $\begin{array}{l}1.064^{* * *} \\
(.10)\end{array}$ & $\begin{array}{l}1.169^{* * *} \\
(.09)\end{array}$ & $\begin{array}{l}1.008^{* * *} \\
(.08)\end{array}$ & $\begin{array}{l}1.473^{* * *} \\
(.06)\end{array}$ & $\begin{array}{l}1.553^{* * *} \\
(.07)\end{array}$ \\
\hline Growth opportunities & $\begin{array}{l}-0.640^{* * *} \\
(.31)\end{array}$ & $\begin{array}{l}-0.432^{* * *} \\
(.24)\end{array}$ & $\begin{array}{l}-0.557^{* * *} \\
(.28)\end{array}$ & $\begin{array}{l}-0.616^{* * *} \\
(.21)\end{array}$ & $\begin{array}{l}-0.519^{* *} \\
(.21)\end{array}$ \\
\hline Privatization deals & & & $\begin{array}{l}0.211 \\
(.40)\end{array}$ & & \\
\hline Privatization stake & & & $\begin{array}{l}0.016^{*} \\
(.01)\end{array}$ & & \\
\hline Privatization value & & & $\begin{array}{l}0.055 \\
(.04)\end{array}$ & & \\
\hline Deals that are public offers & & & $\begin{array}{l}1.163^{*} \\
(.70)\end{array}$ & & \\
\hline Industry concentration & & & $\begin{array}{l}1.764^{* * *} \\
(.30)\end{array}$ & & \\
\hline Income per capita & $\begin{array}{l}-7.734^{* * *} \\
(.42)\end{array}$ & $\begin{array}{l}-5.099 * * * \\
(.25)\end{array}$ & $\begin{array}{l}-4.808^{* * *} \\
(.28)\end{array}$ & $\begin{array}{l}-2.943^{* * *} \\
(.13)\end{array}$ & $\begin{array}{l}-2.826^{* * *} \\
(.13)\end{array}$ \\
\hline $\begin{array}{l}\text { Obss. } \\
R^{2}\end{array}$ & 8625 & 10,527 & 9275 & 16,666 & 16,666 \\
\hline$R^{2}$ & 0.19 & 0.16 & 0.18 & 0.16 & \\
\hline
\end{tabular}

\section{Appendix D. Additional evidence and robustness checks for the telecom study}

Sample and variable definitions are presented in Appendix A. The dependent variable is the change in the average growth of main lines per employee from 1987-1989 to 2000-2002, unless noted otherwise.

Panel A uses probit estimation to examine the decision to privatize. The dependent variable is a dummy for transfer of ownership stake from government to private holders.

Panel B performs $t$-tests of differences in means are performed on the privatized sector subsample and on the full sample of privatized and public sectors.

Panel C provides additional multivariate tests of property rights effects on performance gains in privatized sectors using a selection model. 
Panel D provides additional tests of privatization and property rights effects on the performance of all (privatized and public) (privatized and public) sectors using a treatment effects model.

Robust standard errors are in the parentheses. Statistical significance at $1 \%, 5 \%$, and $10 \%$ levels is denoted with ${ }^{* * *}$, **, and ${ }^{*}$, respectively.

\begin{tabular}{|c|c|c|c|c|}
\hline & I & II & III & IV \\
\hline \multicolumn{5}{|l|}{ Panel A. Privatization determinants } \\
\hline French legal origin & $\begin{array}{l}-0.280 \\
(.43)\end{array}$ & $\begin{array}{l}-0.253 \\
(.43)\end{array}$ & $\begin{array}{l}-0.480 \\
(.39)\end{array}$ & $\begin{array}{l}-0.591 \\
(.38)\end{array}$ \\
\hline Property rights & $\begin{array}{l}-0.034 \\
(.02)\end{array}$ & $\begin{array}{l}-0.044^{*} \\
(.02)\end{array}$ & $\begin{array}{l}-0.065^{* * *} \\
(.02)\end{array}$ & $\begin{array}{l}-0.062^{* *} \\
(.03)\end{array}$ \\
\hline CPI index & $\begin{array}{l}0.016^{*} \\
(.01)\end{array}$ & $\begin{array}{l}0.016^{*} \\
(.01)\end{array}$ & $\begin{array}{l}0.013 \\
(.01)\end{array}$ & $\begin{array}{l}0.015^{*} \\
(.01)\end{array}$ \\
\hline Primary enrollment & $\begin{array}{l}0.005 \\
(.01)\end{array}$ & $\begin{array}{l}0.005 \\
(.01)\end{array}$ & $\begin{array}{l}0.000 \\
(.01)\end{array}$ & $\begin{array}{l}-0.004 \\
(.01)\end{array}$ \\
\hline Population (logged) & $\begin{array}{l}-0.211 \\
(.28)\end{array}$ & $\begin{array}{l}-0.086 \\
(.24)\end{array}$ & $\begin{array}{l}-0.244 \\
(.22)\end{array}$ & $\begin{array}{l}-0.353 \\
(.26)\end{array}$ \\
\hline Initial GDP per capita (logged) & $\begin{array}{l}0.355^{* *} \\
(.15)\end{array}$ & $\begin{array}{l}0.347^{* *} \\
(.15)\end{array}$ & & \\
\hline Initial GNP per capita (logged) & & & $\begin{array}{l}0.805^{* * *} \\
(.28)\end{array}$ & $\begin{array}{l}1.075^{* * *} \\
(.32)\end{array}$ \\
\hline Main lines (prior) & & $\begin{array}{l}0.002 \\
(.00)\end{array}$ & & $\begin{array}{l}-0.003 \\
(.00)\end{array}$ \\
\hline Obs. & 65 & 65 & 67 & 67 \\
\hline Privatized sectors & \multicolumn{4}{|c|}{ Average performance in sectors that underwent privatization } \\
\hline Performance measure & Obs. & Mean 1987-1989 (before) & Mean 2000-2002 (after) & Diff. \\
\hline \multicolumn{5}{|l|}{ Panel B. Univariate evidence } \\
\hline $\begin{array}{l}\text { - Levels } \\
\text { nof }\end{array}$ & 50 & 74.659 & 168.385 & $93.727^{* * *}$ \\
\hline - Growth rate & 47 & 5.768 & 7.385 & 1.617 \\
\hline Privatized and public sectors & \multicolumn{4}{|c|}{ Performance changes between 1987-1989 and 2000-2002 } \\
\hline Performance measure & Obs. & Privatized sectors & Remained public & Diff. \\
\hline \multicolumn{5}{|l|}{ Main lines per employee } \\
\hline - Levels & 83 & 93.727 & 53.352 & $41.374^{* *}$ \\
\hline \multirow[t]{2}{*}{ - Growth rate } & 74 & 1.617 & 3.495 & -1.878 \\
\hline & I & II & III & IV \\
\hline \multicolumn{5}{|c|}{ Panel C. Property rights and performance gains in privatized sectors } \\
\hline Property rights & $\begin{array}{l}0.496^{* *} \\
(.24)\end{array}$ & $\begin{array}{l}0.552^{* * *} \\
(.20)\end{array}$ & $\begin{array}{l}0.666^{* *} \\
(.15)\end{array}$ & $\begin{array}{l}0.585^{* *} \\
(.23)\end{array}$ \\
\hline Regulator (prior) & $\begin{array}{l}6.320^{*} \\
(3.44)\end{array}$ & $\begin{array}{l}1.631 \\
(3.17)\end{array}$ & $\begin{array}{l}5.754^{* *} \\
(2.93)\end{array}$ & $\begin{array}{l}1.676 \\
(3.18)\end{array}$ \\
\hline Sub-Saharan Africa & $\begin{array}{l}-5.649 \\
(5.56)\end{array}$ & $\begin{array}{l}-10.067^{* *} \\
(4.99)\end{array}$ & $\begin{array}{l}-7.420^{* * *} \\
(2.70)\end{array}$ & $\begin{array}{l}-10.592^{*} \\
(6.07)\end{array}$ \\
\hline GDP per capita (logged) & $\begin{array}{l}1.415 \\
(1.66)\end{array}$ & $\begin{array}{l}0.958 \\
(1.19)\end{array}$ & $\begin{array}{l}1.218 \\
(1.17)\end{array}$ & $\begin{array}{l}0.839 \\
(1.26)\end{array}$ \\
\hline Main lines (prior) & $\begin{array}{l}-0.058^{* * *} \\
(.02)\end{array}$ & $\begin{array}{l}-0.071^{* * *} \\
(.02)\end{array}$ & $\begin{array}{l}-0.070^{* * *} \\
(.01)\end{array}$ & $\begin{array}{l}-0.072^{* * *} \\
(.02)\end{array}$ \\
\hline Full privatization & $\begin{array}{l}4.317 \\
(5.73)\end{array}$ & $\begin{array}{l}4.375 \\
(5.63)\end{array}$ & $\begin{array}{l}4.700 \\
(5.02)\end{array}$ & $\begin{array}{l}4.574 \\
(5.90)\end{array}$ \\
\hline Budget balance & $\begin{array}{l}0.145 \\
(.44)\end{array}$ & & $\begin{array}{l}0.101 \\
(.40)\end{array}$ & \\
\hline Net FDI & & $\begin{array}{l}1.292^{* *} \\
(.57)\end{array}$ & & $\begin{array}{l}1.219^{*} \\
(.72)\end{array}$ \\
\hline Competition (long distance) & $\begin{array}{l}2.315 \\
(1.44)\end{array}$ & $\begin{array}{l}2.811^{* * *} \\
(.98)\end{array}$ & & \\
\hline Competition (local) & & & $\begin{array}{l}2.238^{*} \\
(1.24)\end{array}$ & $\begin{array}{l}3.149^{* * *} \\
(1.21)\end{array}$ \\
\hline Obs. & 58 & 58 & 57 & 57 \\
\hline
\end{tabular}




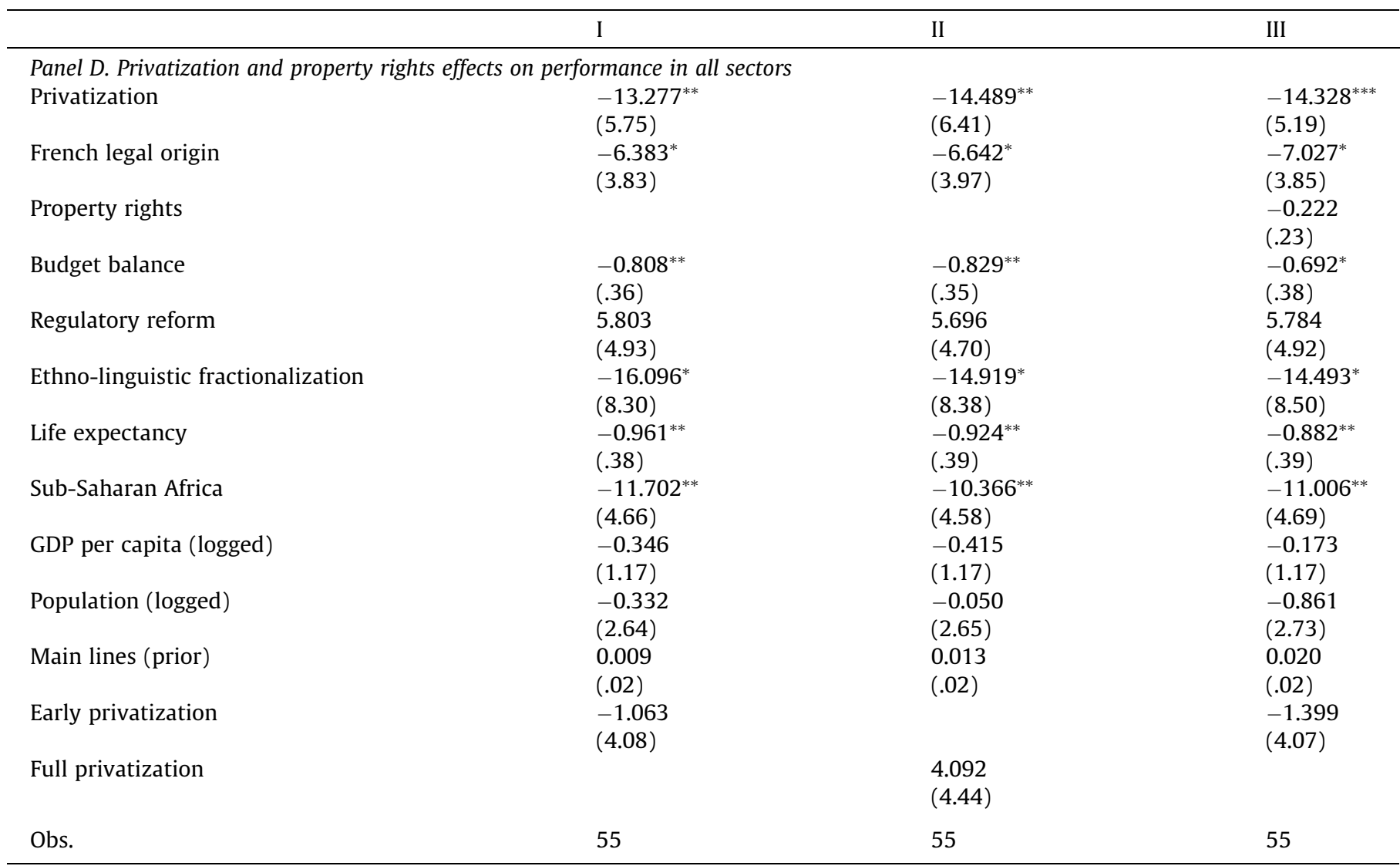

\section{References}

Acemoglu, D., Johnson, S., 2005. Unbundling institutions. Journal of Political Economy 113 (5), 949-995.

Amihud, Y., Lev, B., 1981. Risk reduction as a managerial motive for conglomerate mergers. Rand Journal of Economics 12, 605-618.

Anderson, R., Claessens, S., Djankov, S., Pohl, G., 1997. Privatization and Restructuring in Central and Eastern Europe. Technical Paper 368. World Bank.

Birdsall, N., Nellis, J., 2003. Winners and losers: assessing the distributional impact of privatization. World Development 10, 1617-1633.

Boardman, A., Vining, A., 1989. Ownership and performance in competitive environment: a comparison of the performance of private, mixed, and stateowned enterprises. Journal of Law and Economics 32, 1-33.

Bortolotti, B., D’Souza, J., Fantini, M., Megginson, W., 2001. Sources of Performance Improvement in Privatized Firms: A Clinical Study of the Global Telecommunications Industry. Working Paper. University of Oklahoma.

Boubakri, N., Cosset, J.-C., 1998. The financial and operating performance of newly privatized firms: evidence from developing countries. Journal of Finance 53, 1081-1110.

Boubakri, N., Cosset, J.-C., Guedhami, O., 2005. Postprivatization corporate governance: the role of ownership structure and investor protection. Journal of Financial Economics 76, 369-399.

Claessens, S., Djankov, S., 1998. Politicians and Firms in Seven Central and Eastern European Countries. Working Paper. World Bank.

D'Souza, J., Megginson, W., 1999. The financial and operating performance of privatized firms during the 1990s. Journal of Finance 54, 1397-1438.

D’Souza, J., Megginson, W., Nash, R., 2005. The effects of changes in corporate governance and restructurings on operating performance: evidence from privatizations. Journal of Finance 54, 1397-1438.

Dewenter, K., Malatesta, P., 2001. State-owned and privately-owned firms: an empirical analysis of profitability, leverage, and labor intensity. American Economic Review 91, 320-334.

Dinc, S., Gupta, N., 2011. The decision to privatize: finance and politics. Journal of Finance 66 (1), 241-269.

Djankov, S., La Porta, R., Lopez-de-Silanes, F., Shleifer, A., 2003. Courts. Quarterly Journal of Economics 118 (2), 453-517.

Djankov, S., La Porta, R., Lopez-de-Silanes, F., Shleifer, A., 2008. The law and economics of self-dealing. Journal of Financial Economics 88 (3), 430-465.
Ehrlich, I., Gallais-Hamonno, G., Liu, Z., Lutter, R., 1994. Productivity growth and firm ownership: an empirical investigation. Journal of Political Economy 102 1006-1038.

Ellerman, D., Stiglitz, J., 2000. New bridges across the chasm: Macro- and microstrategies for Russia and other transitional economies. Zagreb International Review of Economics and Business 3 (1), 41-72.

Erel, I., Liao, R., Weisbach, M., 2012. Determinants of cross-border mergers and acquisitions. Journal of Finance 67 (3), 1045-1082.

Fernandes, A., Kraay, A., 2007. Property rights institutions, contracting institutions and growth in South Asia: macro and micro evidence. In: Ahmed, S., Ghani, E. (Eds.), South Asia Growth and Regional Integration. Macmillan India Ltd.

Godoy, S., Stiglitz, J., 2007. Growth, initial conditions, law and speed of privatization in transition countries: 11 years later. In: Estrin, S., Kolodko, G.W., Uvalic, M. (Eds.), Transition and Beyond. Palgrave Macmillan.

Guillen, M.F., Henisz, W., Zelner, B., 2004. International Coercion, Emulation and Policy Diffusion: Market-Oriented Infrastructure Reforms, 1977-1999. Working Paper. University of Pennsylvania.

Gupta, N., 2005. Partial privatization and firm performance. Journal of Finance 60 987-1015.

Gupta, N., Ham, J., Svejnar, J., 2008. Priorities and sequencing in privatization: Evidence from Czech firm panel data. European Economic Review 52 (2), 183208.

Gwartney, J., Lawson, R., Hall, J., 2011. Economic Freedom of the World: 2011 Annual Report.

Hoff, K., Stiglitz, J., 2004a. After the Big Bang? Obstacles to the emergence of the rule of law in post-Communist societies. American Economic Review 94, 753-763.

Hoff, K., Stiglitz, J., 2004b. The transition process in post-Communist societies: Towards a political economy of property rights. In: Tungodden, B., Stern, N. Kolstad, I. (Eds.), Towards Pro-Poor Policies: Aid, Institutions and Globalization. World Bank/Oxford University Press.

Hoff, K., Stiglitz, J., 2008. Exiting a lawless state. Economic Journal 118 (531), 1474 1497.

Kang, J.-K., Kim, J.-M., 2008. The geography of block acquisitions. Journal of Finance 63, 2817-2858.

Kaufmann, D., Kraay, A., Mastruzzi, M., 2009. Governance matters VIII: Aggregate and individual governance indicators 1996-2008. World Bank Policy Research Working Paper 4978. 
ARTICLE IN PRESS

A. Knyazeva et al./Journal of Banking E' Finance $x x x$ (2013) $x x x-x x x$

23

Kedia, S., Panchapagesan, V., Uysal, V., 2008. Geography and acquirer returns. Journal of Financial Intermediation 17, 256-275.

Knyazeva, A., Knyazeva, D., Stiglitz, J., 2009. Ownership changes and access to external financing. Journal of Banking and Finance 33 (10), 18041816.

La Aorta, R., Lopez-de-Silanes, F., 1997. Benefits of privatization - evidence from Mexico. Private Sector 10, 21-24.

La Porta, R., Lopez-de-Silanes, F., Shleifer, A., Vishny, R., 1997. Legal determinants of external finance. Journal of Finance 52, 1131-1150.

La Porte, R., Lopez-de-Silanes, F., Shleifer, A., Vishny, R., 1998. Law and finance. Journal of Political Economy 106 (6), 1113-1155.

La Porta, R., Lopez-de-Silanes, F., Shleifer, A., Vishny, R., 1999. Corporate ownership around the world. Journal of Finance 5, 471-517.

La Porte, R., Lopez-de-Silanes, F., Shleifer, A., Vishny, R., 2000. Investor protection and corporate governance. Journal of Financial Economics 58, 3-27.

La Porta, R., Lopez-de-Silanes, F., Shleifer, A., 2002. Government ownership of banks. Journal of Finance 57 (1), 265-301.

Li, W., Xu, L.C., 2002. The political economy of privatization and competition: crosscountry evidence from the telecommunications sector. Journal of Comparative Economics 30, 439-462.

Masulis, R., Xe, F., Wang, C., 2007. Corporate governance and acquirer returns. Journal of Finance 62 (4), 1851-1889.

Mathur, I., Banchuenvijit, W., 2007. The effects of privatization on the performance of newly privatized firms in emerging markets. Emerging Markets Review 8 (2), $134-146$.

Megginson, W., Nash, R., Van Randenborgh, M., 1994. The financial and operating performance of newly privatized firms: an international empirical analysis. Journal of Finance 49, 403-452.
Megginson, W., Netter, J., 2001. From state to market: a survey of empirical studies on privatization. Journal of Economic Literature 39, 321-389.

Moeller, S., Schlingemann, F., Stulz, R., 2004. Firms size and gains from acquisitions. Journal of Financial Economics 73 (4), 201-228.

Noam, E., 1998. Telecommunication in Latin America. Oxford University Press.

Oran, M., 2004. The Performance of State-Owned Enterprises and Newly Privatized Firms: Does Privatization Really Matter? Working Paper. Arab Monetary Fund.

Stiglitz, J., 2000a. Quid custodiet ipsos custodes? Corporate governance failures in the transition. In: Mut, P.-A., Stiglitz, J.E. (Eds.), Governance, Equity and Global Markets, Proceedings from the Annual Bank Conference on Development Economics in Europe, June 1999, Conseil d'Analyse Economique, Paris.

Stiglitz, J., 2000b. Whither reform? Ten years of transition. In: Pleskovic, B., Stiglitz, J.E. (Eds.), Annual World Bank Conference on Economic Development. World Bank, Washington.

Stiglitz, J., 2002. Globalization and its Discontents. WW Norton, New York.

Sun, Q., Tong, W., 2003. China share issue privatization: the extent of its success. Journal of Financial Economics 70, 183-222.

Sabirianova, K., Svejnar, J., Terrell, K., 2012. Foreign investment, corporate ownership, and development: Are firms in emerging markets catching up to the world standard? Review of Economics and Statistics 94 (4), 981-999.

Villalonga, B., 2000. Privatization and efficiency: differentiating ownership effects from political, organization, and dynamics effects. Journal of Economic Behavior and Organization 42, 43-74.

Wallsten, S., 2001. An empirical analysis of competition, privatization, and regulation in Africa and Latin America. Journal of Industrial Economics 49, 1-19. Wallsten, S., 2002. Does Sequencing Matter? Regulation and Privatization in Telecommunication Reforms. Working Paper, World Bank.

Please cite this article in press as: Knyazeva, A., et al. Ownership change, institutional development and performance. J. Bank Finance (2013), http://

dx.doi.org/10.1016/j.jbankfin.2013.02.017 